\title{
Analysis and comparison of potential resources and new energy policy of Madagascar island; A review
}

\author{
Modeste Kameni Nematchoua a, b, * \\ ${ }^{a}$ Beneficiary of an AXA Research Fund Postdoctoral Grant, Research Leaders Fellowships, AXA SA, 25 Avenue Matignon, 75008, Paris, France \\ ${ }^{\mathrm{b}}$ University of Liège, Urban AndEnvironmental Engineering Department, Local Environment Management \& Analysis (LEMA), Allée de La Découverte9, \\ Quartier Polytech 1, BE-4000, Liège, Belgium
}

\section{A R T I C L E I N F O}

\section{Article history:}

Received 23 November 2019

Received in revised form

9 February 2021

Accepted 14 February 2021

Available online 2 March 2021

\section{Keywords:}

Resource potential

New energy policy

Madagascar Island

Review

\begin{abstract}
A B S T R A C T
The aim of this research is to review the status and current trends about energy resources production potential and new energy policies in Madagascar to suggest possible solutions to help the government in its sustainable policy development. The results of this investigation showed that, nowadays in Madagascar, more than $80 \%$ of natural potential is remaining not exploited. What is more, in order to satisfy the demand of energy, the country will need to use up to $12,000 \mathrm{MW}$ of its hydroelectric potential and $10 \%$ of its solar potential that can be easily reached with a good energy policy. In this sense, an operating of only $20 \%$ of solar, hydraulic and wind power resources, in Madagascar, can cover the energy needs of all five Indian Ocean countries on several years and, in particular, solar potential resulted significant in coastal zone of Madagascar.
\end{abstract}

(C) 2021 Elsevier Ltd. All rights reserved.

\section{Introduction}

During the process of evolution, man did not stop in his desire to improve his living conditions. The giant step in the history of humanity was, undoubtedly, man's mastery over fire. Modernization gave way to volatility, and new techniques were born [1]. Energy occupies a central place in the struggle against poverty. The services connected with energy contribute in a most meaningful manner to the impetus in the economic sector and in social development, as well as to all human activities in their endeavor for better conditions in life. Energy is an irreplaceable resource that controls every aspect of life and supports human welfare. It is vital for the growth of a nation's economy and is what sustains development. Globally, over the past several decades, there has been a notable increase in energy consumption at the level of emergent countries, to sustain their growth. This had, in effect, caused an increase in the cost of energy, notably for petroleum products. Nowadays, more than ever, the energy requirements of man are enormous and still growing. Worldwide, every country needs energy, as it is the main ingredient required for development [2]. According to Michel Maldague [3], globally, environmental problems associated with production and transportation, as also transformation and use of energy sources, have increased, as evidenced by the increase in the greenhouse effect; as also deforestation, imputable among others, to unplanned felling of trees for firewood. For specialists in development, energy consumption is an indicator of the level of development in the dynamism of economy of a country [8-11]. Thus, each country develops its own energy policy by ensuring the availability of energy resources in sufficient quantities corresponding to the needs of its users in terms of quality, efficiency and safety, and which are accessible physically and economically [4]. The low level of consumption of modern energy prevalent in sub-Saharan Africa is even more striking when one considers the consumption of electricity [17]. Many countries in Sub-Saharan Africa have low levels of access to electricity [46]. Electricity consumption is confined to commercial and industrial enterprises as well as high-income households [5]. Much of the world's energy is currently produced and consumed in a manner that cannot be sustained for very long, and these levels are significantly higher than the environmentally friendly sources of renewable energy [2,12]. New economic, environmental and social challenges include the increase in petroleum products and concern

\footnotetext{
* Beneficiary of an AXA Research Fund Postdoctoral Grant, Research Leaders Fellowships, AXA SA, 25 Avenue Matignon, 75008, Paris, France.

E-mail addresses: kameni.modeste@yahoo.fr, mkameni@uliege.be, Modeste.Kameni.Nematchoua@ulb.be.
} 
for the preservation of the environment: pollution, climate change, reducing carbon emissions and sustainable management of natural resources [12]. Action taken at the international and national levels, and addressed by various stakeholders, including state decisionmakers, highlighted the awareness of these issues and their implications on the energy sector [6,21-25]. Madagascar is almost entirely within the tropics. It is located between $20^{\circ} 00 \mathrm{~S}$ and $47^{\circ} 00 \mathrm{E}$. It consists of 22 regions. Madagascar is an island in the Indian Ocean with an area of $592,000 \mathrm{~km} 2$. It is the fourth largest island in the world. It is separated from Africa by the Mozambique Channel about $400 \mathrm{~km}$ away. The island had 23,812,681 inhabitants in 2015 , of which more than $75 \%$ lived in rural areas, with a population growth rate of around $2.7 \%$ per year. The current density is $41 / \mathrm{km}^{2}$. The country's economy is mainly based on agriculture. The climate of Madagascar is divided into four sections: humid tropical climate, altitude tropical climate, tropical climate of transition and dry tropical climate. The types of season are the dry season from April to October; this season is named so due to the virtual absence of rain. The rainy season, from November to March, is often punctuated by fleeting, but regular rains, which occur mostly in the early evening or overnight. The annual electricity consumption is $44 \mathrm{kWh} /$ capita, and the annual per capita energy consumption is $0.2 \mathrm{PET} / \mathrm{hab}$ [4]. Its energy intensity is Btu 196,275 per US dollar [6,7].Madagascar has valuable hydrocarbon resources and renewable energy operating at less than $5 \%$ of its potential [4].More than $70 \%$ of its population lives in a rural environment with agriculture as its main activity [7].In Madagascar, energy is obtained either from the development of natural resources, such as biomass, forest residues, crop residues, water, sun and wind, or through the import of petroleum products $[30,31]$.The country does not produce oil, despite the numerous prospecting works carried out there [30]. In Madagascar, since 2000, the energy sector has not been spared by the effects of the weakening by various political crisis that traversed the country [4]. Following the economic crisis and strikes that take place regularly on its territory, has delayed the development of its energy resources.

Nowadays, the Government, through a New Energy Policy (NEP) presents a revitalization of the sector, and allows rapid progress, "palpable" and continuing, in the economic, social and environmental fields. The development of the NEP is based on national and inter-institutional consultation obtained through a transparent process of development, which draws its lessons from past experiences. This NEP is part of the National Development Plan 2015-2019 [6,7]. It reflects the Government's commitment to clean the energy scene and provide a favorable framework for investments in the sector, especially by taking advantage of new technologies that allow a significant saving of energy [7].

The aim of this study is to review the status and current trends in potential resources and to analyze the energy production and new energy policies in all the sectors in Madagascar to suggested some solutions to help the government in its new sustainable development policy. It must be highlighted that Madagascar is one of most great island in the world and can be classified as one of the African giants in potential resource, in the same category as Congo Kinshasa. In consequence, this research work can be identified with an innovative objective due to there is no work showing in detail the different resources of this region yet and, what is more, despite its current political situation and the poverty of its population, it has significant potential resources which are huge and untapped. In consequence, to reach this objective, this research is divided in five sections: The section 2 shows an overview on the potential resources in Madagascar; the section3 analysis solar radiation in several region in Indian Ocean; the section4presents the new energy policy of Madagascar Island and the last section shows the energy policy of the island by $\mathbf{2 0 3 0}$.

\section{Literature review on potential resources in Madagascar}

Madagascar Island has many potential resources and climate, as shown in Fig. 1.

Fig. 2 shows the distribution of the average energy consumption in Madagascar during the last 10 years, between 1994 and 2004, by the various sectors. About $62 \%$ of the energy consumption was in the residential sector, $27 \%$ in the tertiary sector, and $8.9 \%$ was for transportation. Only $0.7 \%$ of the energy used was in the primary sector. Between 2017 and 2018, surveys showed that $62.8 \%$ of total energy was consumed in households [60]. Overall, the primary sector consumes only $0.1 \%$ of the energy produced in the country, compared to $8.6 \%$ for the secondary sector and $28.6 \%$ for the tertiary sector, of which $10.7 \%$ relates to transport [60]. In 2017, Total primary energy consumption was 0.058 Quad Btu, with a distribution of $20.7 \%$ of Coal, $65.5 \%$ of Fuel, and $13.8 \%$ of renewable energy and other $[4,14]$. This total primary energy consumption, was three (03) times more small, compare to the one of Cameroon (0.161 Quad Btu) [17,31]; it was 104 times more small than the one of South Africa (6.033 Quad Btu); and was 171 times more small than the one of France (9.903 Quad Btu).

These statistical analyses show that energy is most used in the residential sector in Madagascar. These results are in agreement with those found by Kameni et al. [2].Globally, in Sub-Saharan Africa, and similarly in many countries in Asia and Europe, a good quantity of energy is consumed in the residential sectors and in the industrial sector. The energy information system in Madagascar in its presentation of the energy balance, showed that in 2017, the

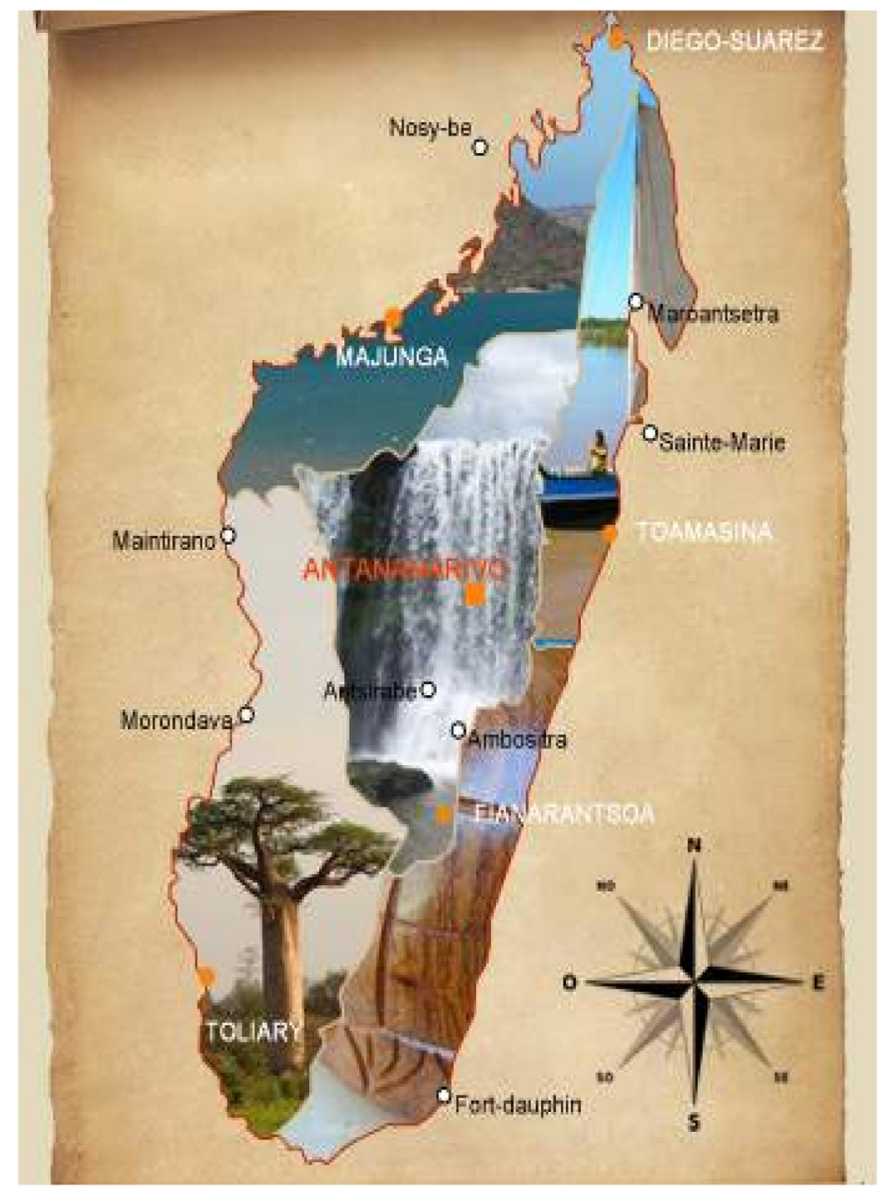

Fig. 1. Distribution of natural resources in different regions of Madagascar. 


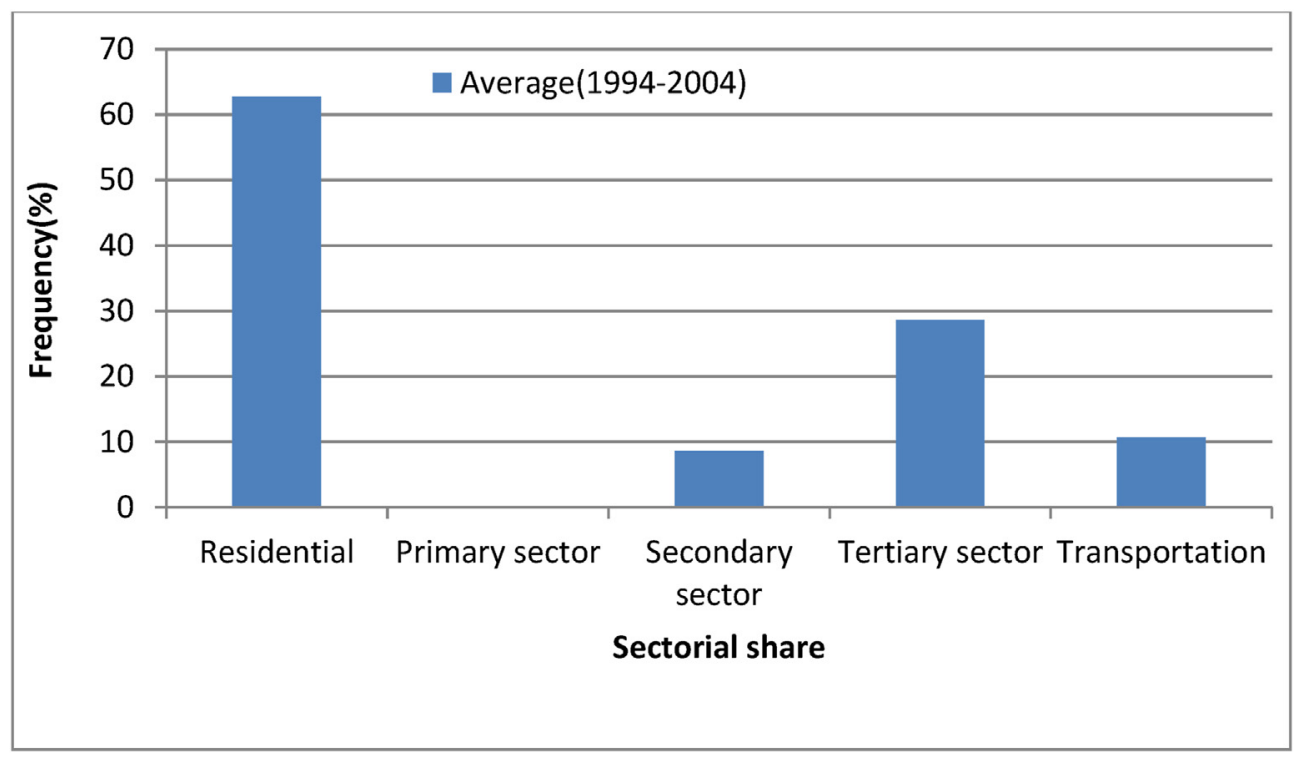

Fig. 2. Energy consumption in Madagascar (1994-2004).

energy production was estimated at 6433 kilo tons oil equivalent (ktoe), and imports of $1183 \mathrm{ktoe}$, to give a total energy supply of 7671 ktoe [60]. The 2838 ktoe were transformed into electricity, fuel, wood energy and Charcoal. In addition, the final energy consumption, estimated at 5524ktoe, was distributed between the needs of transport, industry, and other sectors $[4,60]$. In the next sub-paragraph, we will describe three important sectors in Madagascar (Electricity, Fossil fuels and Renewable energy):

\subsection{Electricity}

According to experts of the Ministry of Energy and Hydrocarbon, today, very few people in Madagascar have access to modern sources of energy, and this seriously hampers their development $[4,30]$.In addition, people who have no access must use energy sources of inferior quality, which are inefficient and often polluting [31].Overall, access to electric power remains low in Madagascar. In rural areas, where over $70 \%$ of the population lives, less than $5 \%$ of the population have access to electricity [33,35].In urban areas, less of $10 \%$ of the households had electricity in 2001,while the rate was around of $15 \%$ in 2010 [2,6].Paraffin remains the main source of lighting for Malagasy households even to this date [7].The total net production of electricity in Madagascar was 832,741 MWhin 2001, and reached 1,267,647MWhin 2011.Since 2001, the production of electric energy has increased [1]. The share produced by thermal power plants has increased from 268,796 MWh in 2001, representing $32 \%$ of the total production to 577,302 in 2011 , representing $45.5 \%$ of the total production [32-35].Compared to this, the production from hydroelectric power plants reached 563,945 MWh in 2000 , representing $68 \%$ of the total production, to reach 690,337 MWh in 2011, representing 54\% of the total production [34,35].

In 2017, the company responsible for distributing electricity in Madagascar (JIRAMA), only registered 49,9067 subscribers, who do not even make up the $20 \%$ of Malagasy households [30]. In 2018, in rural areas, only $5 \%$ of the population access to modern electricity, despite the liberalization of the electricity sector [30].

Although production in the absolute value of electricity has increased, the share of hydroelectric power production decreased compared to the contribution of the production of thermal power plants [2]. Generally, the electrification rate is very weak in many countries in Africa. South Africa accounts for $45 \%$ of total electricity generated in Africa, while North Africa accounts for 30\% [5]. This effectively leaves Sub Saharan Africa (where $80 \%$ of the continent's population resides) with only $24 \%$ of total electricity generated in Africa [5].In Fig. 3, we have shown the energy consumption in Madagascar in 2011.Biomass contributes 93\% of the consumed energy in Madagascar. In addition, $6.9 \%$ and $0.1 \%$ of energy consumption comes from oil products and renewable energy. According to Fig. 4, from 2001 to 2011, hydroelectric power was the main source of electricity, followed by thermal power. The total electricity generated from solar sources still stays less than 100 GWh every year. The main origin of primary energy in Madagascar is the biomass. These results are similarly at the case of many countries in Sub-Saharan Africa [5].Nowadays, the electrification rate in Madagascar is estimated at $15 \%$, compared to $57 \%$ in Senegal and $80 \%$ in South Africa, which is one of the lowest rates in sub-Saharan Africa. This situation is a disincentive for the implementation of major energy-consuming industrial projects, such as mining, oil and gas. It does not allow existing businesses to be competitive, nor does it allow households to improve their living conditions.Fig. 5 shows the distribution of energy consumption in some sectors. Between 2001 and 2012. An average of 390 GWh of energy was consumed by the residential sector [60]. In the industrial sector, the average energy consumption varied from $250 \mathrm{GWh}$ to $300 \mathrm{GWh}$ for the same period. Less than $5 \%$ of this energy was used for "public lighting" every year [30,31]. We deduce that in Madagascar, this last decade, energy has been more consumed in residential sector. This conclusion was similarly at those deduce by Kameni et al. [2], in their last study in Cameroon. It is seen that, in2018, more than 110 diesel power plants supplied 296.5 MW out of a total installed capacity of $428.1 \mathrm{MW}$. This is because the country's electricity needs are expected to reach 700 MW by 2030 $[6,7]$. Table 1 shows the electricity consumption during these last years. It is seen that from 2000 to 2018, energy consumption increased up to $200 \%$ (from 0.7 to 2.1 billion of $\mathrm{kWh}$ ). Maybe, because of the creation of new industries in Madagascar during this period, which use electricity as main energy source. It is also very interesting to notice that between 2006 and 2010, electricity consumption is stable. 


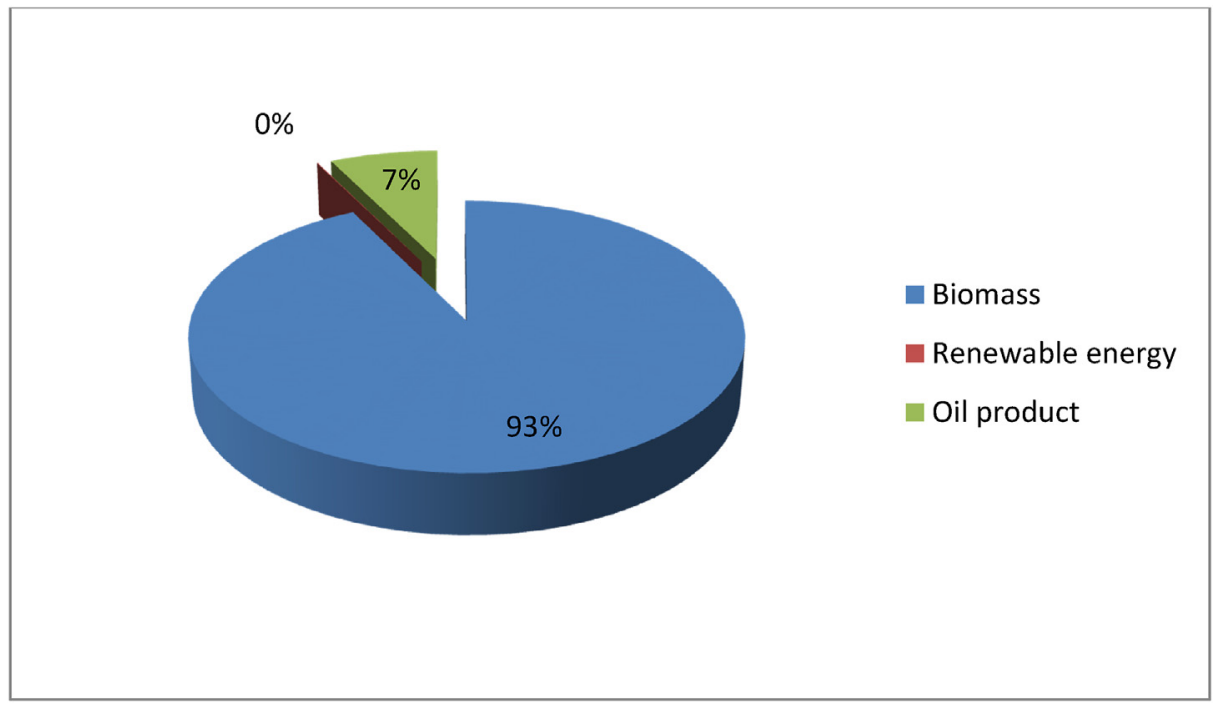

Fig. 3. Energy consumption in Madagascar (2011).

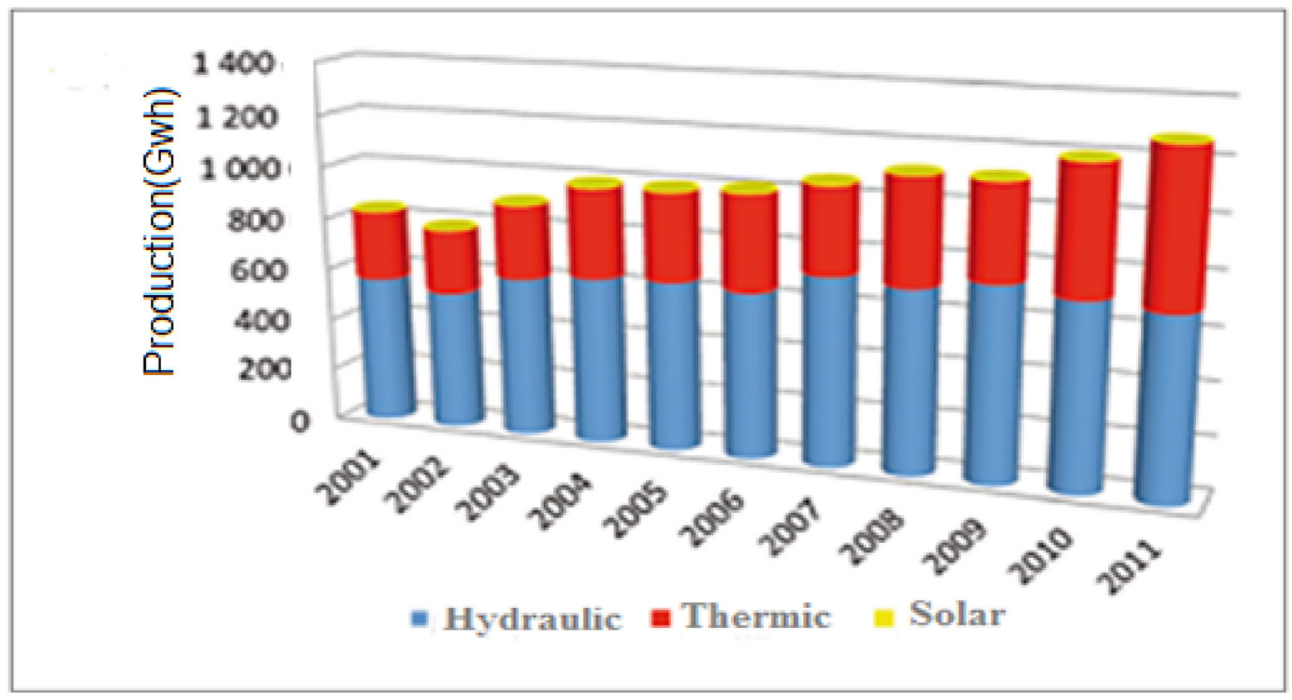

Fig. 4. Electricity production between 2001 and 2011 [6].

In the next sub-section, we will give some information regarding fossil fuel.

\subsection{Fossil fuels}

The most common primary source of energy worldwide is still oil and its derivatives. Indeed, oil has placed man where he is now $[43,44]$, to cite only the transportation industry, electricity and other key sectors of global economy. However, fossil fuels have had a devastating effect on the environment as they contribute immensely to the deterioration and depletion of the ozone layer $[39,41]$.This situation is causing a great deal of concern, and currently, the main topic of world debate is the issue of "Global Warming". Hence, to try to save, or at least to preserve the planet, researchers have developed new sources of energy. These energy sources that are the alternatives to fossil fuels are called "Renewable Energies". The case of oil products is given in the next section.

\subsubsection{Oil products}

As we have shown in Fig. 6, in 2011, gasoil and jet oil constituted $54 \%$ and $17 \%$ of petroleum products. On the other hand, high-octane petrol, fuel oil and gas represented $15 \%$, 13 and $0.9 \%$, respectively, of these consumed products. Only $0.2 \%$ of kerosene was used this year. Fig. 7, gives the volume of consumption of petroleum products between 2006 and 2011.During the period 2006-2011, an average of $7191 \mathrm{~m}^{3}, 405,634.5 \mathrm{~m}^{3}$ and $108,609 \mathrm{~m}^{3}$ of gas, gasoil and jet oil, respectively, were used every year [30]. Kerosene amounting to $626.5 \mathrm{~m}^{3}$ was used. In 2006, the total consumption of oil products was $650,430 \mathrm{~m}^{3}$. It was $685,789 \mathrm{~m}^{3}$ in $2007,634,722 \mathrm{~m}^{3}$ in 2009 , and $777,902 \mathrm{~m}^{3}$ in 2011 [30,31].The estimated energy losses show that almost half of the resources are consumed for lighting and electricity purposes. This is mainly because of the low illumination output of paraffin (estimated at 4\%).The estimated annual loss of paraffin consumption accounts for about 2548 TJ, which corresponds to an annual electricity loss of $1875 \mathrm{TJ}$ [6].The oil imports bill of the country was $\$ 241$ million in 2009 , and $\$ 509$ million in 2013.Thus, it can be seen that it doubled between 2009 and 2013 


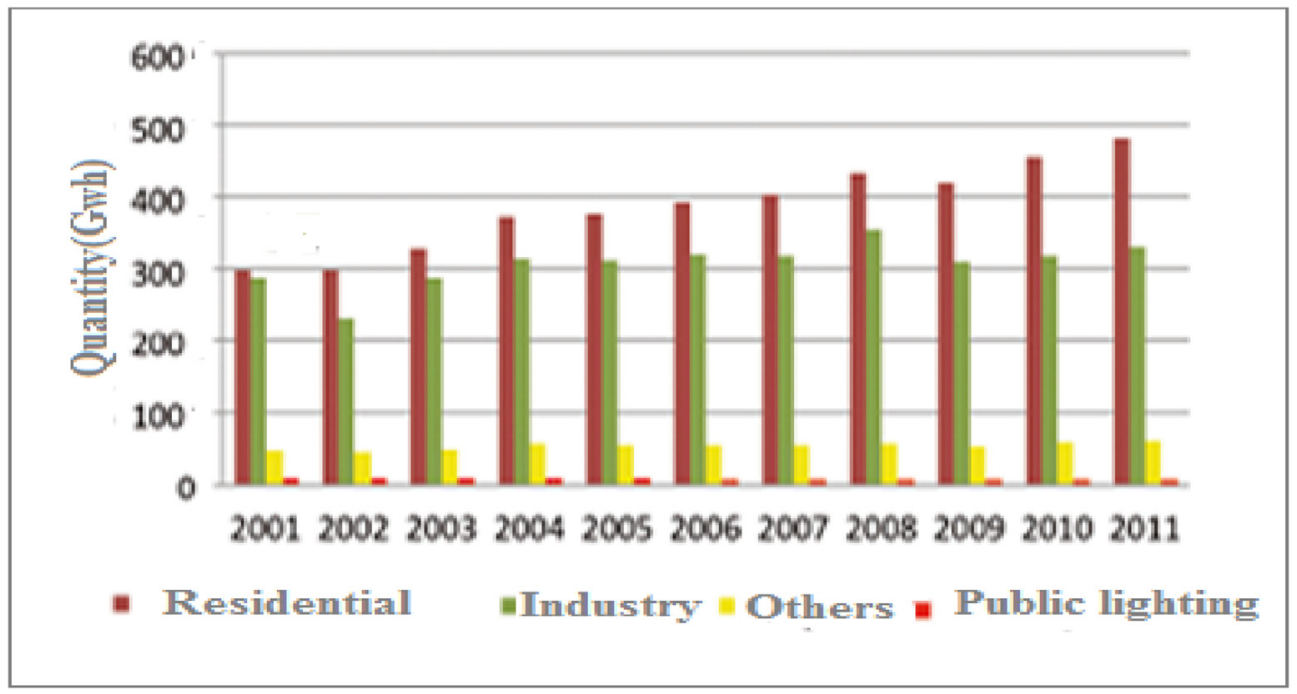

Fig. 5. Distribution of energy consumption in some sectors (2012).

Table 1

Electricity consumption from 2000 to 2019 in Madagascar.

\begin{tabular}{|c|c|c|c|c|c|c|c|c|c|c|c|c|c|c|c|c|c|c|c|c|}
\hline Year & 2000 & 2001 & 2002 & 2003 & 2004 & 2005 & 2006 & 2007 & 2008 & 2009 & 2010 & 2011 & 2012 & 2013 & 2014 & 2015 & 2016 & 2017 & 2018 & 2019 \\
\hline $\begin{array}{l}\text { Electricity } \\
\text { Billion (kWh) }\end{array}$ & 0.7 & 0.8 & 0.8 & 0.9 & 1.0 & 1.0 & 1.1 & 1.1 & 1.1 & 1.1 & 1.2 & 1.3 & 1.6 & 1.7 & 1.8 & 1.9 & 2 & 2.1 & 2.1 & - \\
\hline
\end{tabular}

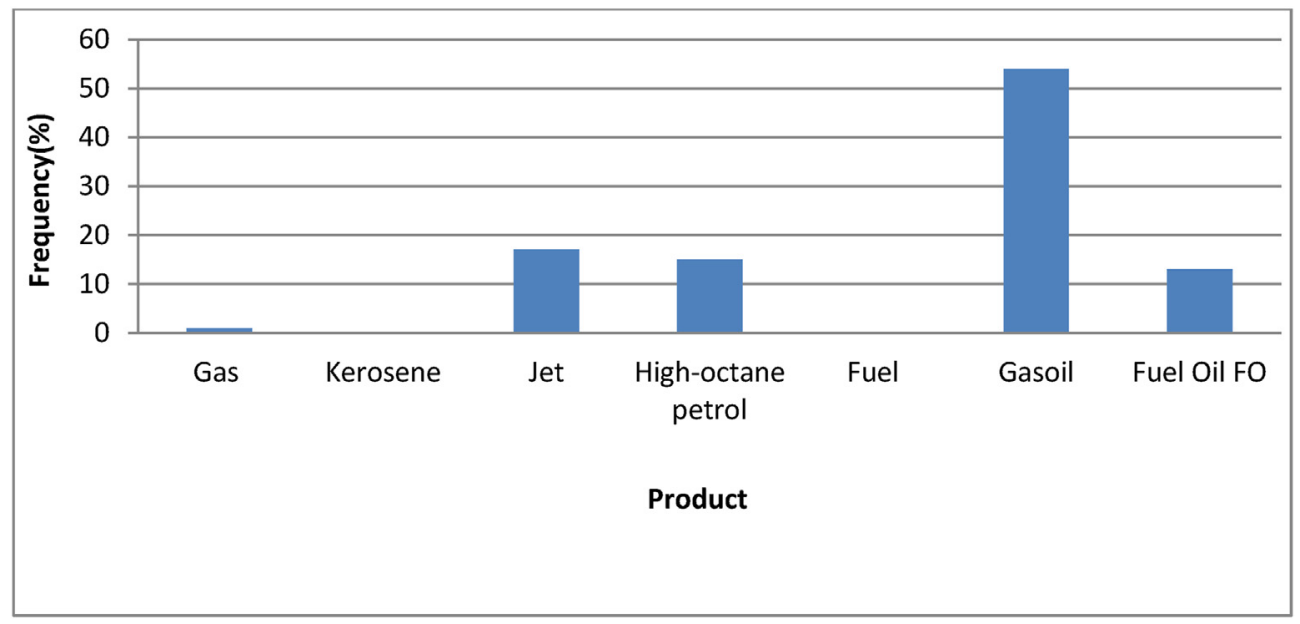

Fig. 6. Total oil product consumption in 2011.

[6].According to the latest report of the National Institute of Statistics, oil consumption has almost increased from $3 \%$ to $4 \%$ between 2017 and 2018, compared to the year 2015, which was estimated at 859,496 $\mathrm{m} 3$ [61].The total amount disbursed by the Public Treasury in Madagascar as part of oil subsidies amounted to 4.2 billion euros on August 30, 2018 [61].

Madagascar is not an oil producer country. All the oil products consumed in Madagascar come from others countries. That why, the boom price, consequently to the strong apply of population. Regarding the last report of EIA, the energy mix of Madagascar was constituted of $65.3 \%$ of oil products in $2013 ; 67.3 \%$ in $2014 ; 68.4 \%$ in 2015; and 65.5\%in 2016 and 2017 [43]. An analysis of coal is carried out in next subsection.

\subsubsection{Coal}

Coal plays a strategic role in generation of electricity, and about $40 \%$ is used worldwide $[42,45]$. The use of coal could contribute to lowering the cost of electricity in Madagascar, as is happening in many countries, including those of "Sakoa city", which are being studied by Thai companies, as also the site of "Imaloto", located in the southwest of the country, which will be operated by a company from South Africa [20,28].The results of the research on the Thai Society Madagascar Consolidated Mining SA would show a good quality of thermal coal reserves, which is estimated at 180 million tones [28].It seems that part of the production of coal from these sites would be exported, and the remainder would be utilized by the Malagasy Ministry of Energy to produce electricity. We deduce, after analyze of these data, that Madagascar has enormous coal 


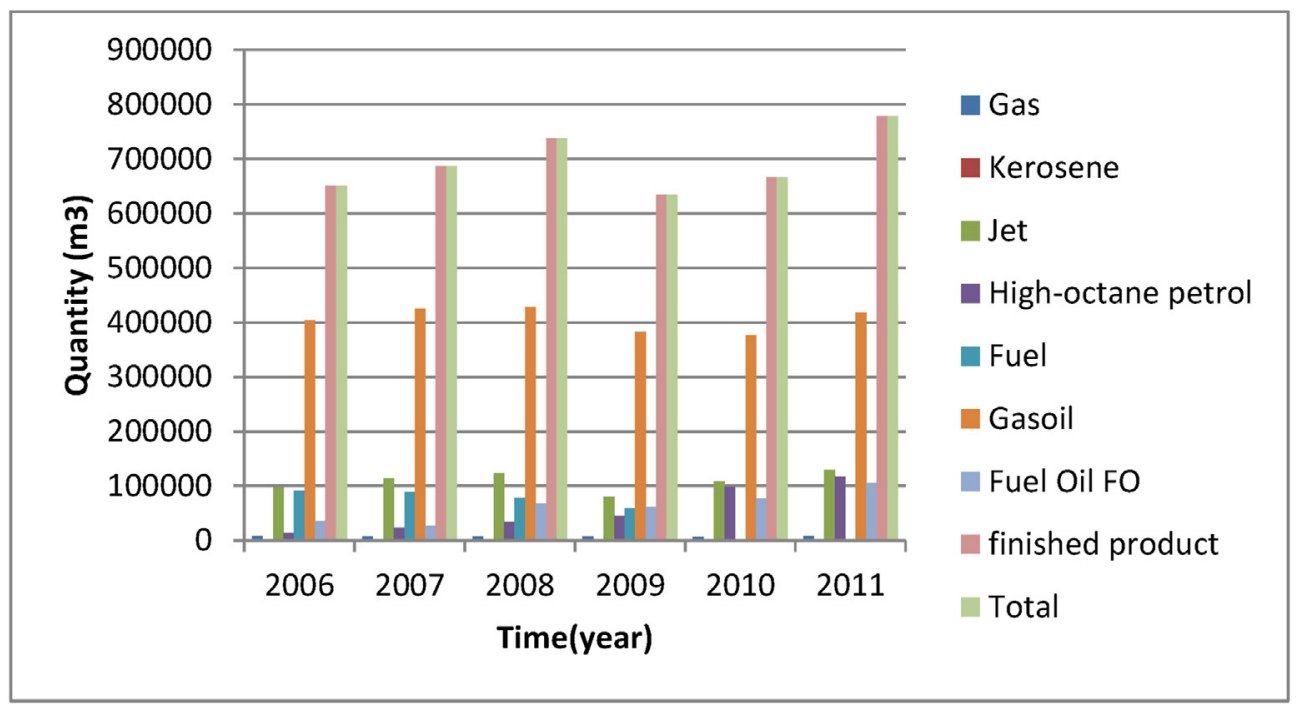

Fig. 7. Volume of petroleum product consumption between 2006 and 2011.

reserve. This resource is very solicited in residential sector. A policy has been established this last years by Malagasy government to fight against the deforestation. In Madagascar, domestic energy needs are mostly covered by charcoal. According to the Ministry of Energy, between 2017 and 2018, a Malagasy family consumed an average of between 50 and $100 \mathrm{~kg}$ of coal per month [6,7]. Indeed, coal is cheaper compared to other energy sources, such as gas, oil etc. Presently, charcoal provides almost $90 \%$ of the cooking energy to city dwellers. In addition, the energy mix in Madagascar was constituted to $17.3 \%$ of coal in $2014 ; 15.8 \%$ in 2015 , and $18.7 \%$ in 2017 [7]. The coal rate consumed is over of the average in Africa. Statistic details regarding renewable energy rate is given in the next subsection.

\subsection{Renewable energy}

Madagascar has vast reserves of renewable energy (hydro, solar, wind ...), but the overall energy consumption is still very low. This energy consumption is dominated by wood and its derivatives, which account for over $80 \%$ of the demand [1].Up to now, the renewable energies, are again innovating concept in Madagascar. The renewable energy source has a significant effect on the production and national consumption. The hydroelectric potential which constituted the $55.5 \%$ of national energy was used just around $2.5 \%$, in 2018 [30]. Despite this, the cost of energy is still too high for the citizens of Madagascar, to contribute effectively to social and economic development of the country [13]. An estimation of solar energy is showed in the next subsection.

\subsubsection{Solar potential}

With an estimated potential of around $2000 \mathrm{kWh} / \mathrm{m}^{2} /$ year in 2018, Madagascar is ranked as one among the countries, worldwide, as being rich in solar energy [1]. This energy is currently used for cooking, heating, drying, lighting, conservative medicine, air conditioners and pumps [2]. Over one thousand solar photovoltaic systems have been installed since the 1990sin Madagascar. These are tools that support social and community activities in rural areas, and in communities that do not receive electricity. Their integration into social programs should be more widespread: health, education, security, public lighting, telecommunications, etc. Solar and thermal power also have abundant opportunities to make inroads into urban areas. The gradual replacement of heating systems in hotels, hospitals and homes contributes to clipping the demand during peak periods. Several areas of the island have over $2800 \mathrm{~h}$ of sunshine per year $[13,14]$. Currently, more than14 regions in Madagascar have a radiation level greater than $5.500 \mathrm{~W} / \mathrm{m} 2$ [2].Two photovoltaic plants with a production capacity of 7 and $8 \mathrm{MW}$ are under construction in the country, and financed by Switzerland. An analysis of hydroelectric potential is studied in the next section.

\subsubsection{Hydroelectric potential}

Madagascar island has significant hydroelectric resources located mainly in the central, northwest, north and eastern regions [2]. The hydroelectric potential of the country is recorded in the order of 7,800 MW distributed throughout the island, but only less than $140 \mathrm{MW}$ are utilized in 2016, representing approximately $1.3 \%$ of the total $[13,14]$.This power is mainly distributed across the interconnected networks of Toamasina, Antananarivo and Fianarantso acities [1].The country's largest hydroelectric power plant is the one in Andekaleka city, which has two turbines of $29 \mathrm{MW}$ each, and 12 service stations connected to the network in Jirama [6]. During the global petroleum crisis, in this context, it was difficult to establish a direct investment/connection in the energy sector, firstly, in the heavy hydroelectric potential of the country [30].There is a renewed revival of interest in hydroelectric power, and the national policy gives priority to its development [15-19]. All the above results show that hydroelectric energy technology is again weak in Madagascar. Only one per cent of existent potential was harnessed. Overview, Africa has massive hydropower capacity, of which less than $7 \%$ has been harnessed. Plans are underway to exploit some of this potential [59]. In this sense, last year (in 2018), only $1.6 \%$ of existing hydroelectricity capacity, estimated at around $8 \mathrm{GW}$ was exploited. The report 2017 of International Energy Statistics, explained that, in Africa, the two countries with hydroelectricity potential the highest are Congo Kinshasa which is 11 times higher than this one of Madagascar Island, and Cameroon which was 6 times higher than Madagascar Island. The case of wind potential is given in the next section.

\subsubsection{Wind potential}

Madagascar has great potential for production of wind energy. In this country, there are three types of winds, namely, the coastal winds, local winds and winds from the ocean, with trade winds and cyclones [13]. Energy that can be derived from wind resources is 
considerable, but not uniformly distributed over the national territory. For example: the north zone has an annual average wind speed of between $6 \mathrm{~m} / \mathrm{s}$ and $8 \mathrm{~m} / \mathrm{s}$, at a height of $50 \mathrm{~m}$; in the central region (from $16^{\circ}$ to $24^{\circ}$ of the south latitude), the annual average wind speed is between $6 \mathrm{~m} / \mathrm{s}$ and $6.5 \mathrm{~m} / \mathrm{s}$, at a height of $50 \mathrm{~m}$; in the south zone, the annual average wind speed is greater than $6.5 \mathrm{~m} / \mathrm{s}$ at a height of $50 \mathrm{~m}$ [2-14]. Finally, in the far south, the average wind speed varies from $8 \mathrm{~m} / \mathrm{s}$ to $9 \mathrm{~m} / \mathrm{s}$, at a height of $50 \mathrm{~m}$. The setting up of hybrid power plants should be seriously considered in future strategies. Cap Diego city and the surrounding area is truly the area to focus on in the northern region of Madagascar, as the ideal location to establish and develop the first wind power project [28-31].Indeed, many sites can be identified that satisfy the requirements of feasibility. According to the report in 2017of the Diagnosis of Energy Sector [14], Madagascar could have a staggering potential of over $2000 \mathrm{MW}$ of wind power [1]. These results show that Madagascar has huge potential for production of wind energy. In north and far south of Madagascar, the wind speed is higher than others regions. It can be due to the proximity to the sea. Despite all the wind potential distributed in several regions in Madagascar in 2018 , only $0.1 \%$ of energy consumption come from wind [30]. One of great challenge is to increase up to $5 \%$ the wind energy in the future. Globally, an additional $50 \mathrm{MW}$ of wind power could be available by the end of 2020 , the cost of the initiative is $\$$ 80 million, according to experts from the Ministry of Energy. Madagascar Island strongly depends of the energy from biomass as describe in the next sub-section.

\subsubsection{Biomass potential}

Madagascar has a huge potential for production of power from biomass. It represents about $90 \%$ of the primary energy resources used in the country [13].The bio-energy sector is very active. This refers especially to bio-ethanol that is obtained from sugarcane and vegetable oil, and could replace gasoline used in engines, or as fuel for domestic cooking [2].Madagascar has had for a long time a global phenomenon of degradation of forest resources. Even as forestry problems intensify, the forest administration has not changed significantly in either its means or its modalities. The wood energy sector represents $93 \%$ of energy deals in Madagascar [54,55].It is mainly provided by thousands of small producers [33]. The increase in charcoal consumption by urban and suburban households is the main factor for pressure on forest resources. The total annual wood consumption was 18.3 million m3 (about 12.7 million tons) in 2015, divided between 56\% (10.3 million $\mathrm{m} 3$ per year) of firewood and 44\% (8.0 million $\mathrm{m} 3$ ) turned into charcoal [6].Natural forests that supply the major consumption centers are most at risk in terms of depletion of resources. More than 715,000 urban and suburban households are the biggest consumers of coal [14].In 2016, Madagascar had a significant forest cover (over $21 \%$ of the territory, more than $124,000 \mathrm{~km}^{2}$ ) [7].CIRAD and its Malagasy and Brazilian partners started in 2012 the first biomass thermoelectric power plant in Madagascar. This unique equipment produces electricity at a cost of $0.24 € / \mathrm{kWh}$, which is half that of a diesel generator, and is powered by eucalyptus wood.

Fig. 8 shows that Madagascar occupied an important place in sub-Saharan Africa, with regard to biomass energy. Consumption of modern energy in sub-Saharan Africa is very low. Between 1980 and 2000, per capita consumption of modern energy in East and South Africa has remained small and stagnant, falling from an average of $317 \mathrm{kgoe}$ (kilograms of oil equivalent) to $292 \mathrm{kgoe}$. The low levels of modern energy consumption prevalent in subSaharan Africa are even more striking when one considers electricity consumption [46].The estimated potential of wood production in Madagascar is shown in Table 2. Nowadays, about 95\% of households use firewood for cooking, causing large-scale deforestation (Energy information system, 2018).

\subsubsection{Geothermal potential}

Geothermal manifestations are widespread in Madagascar, but further studies have not been conducted to determine their different characteristics [1].The exploitation of geothermal resources for energy is nonexistent here, although a thermal study center has been operating for more than 30 years [6,14].According to government's rapport of Madagascar and institute of sustainable development [31,49],the different studies on resources across the island summarize most geothermal resources of Madagascar as not being the best developed for production of electrical energy, but they are good for the direct production of thermal energy (heating, drying of agricultural products, fisheries, air conditioning, etc.). All these information showed that, geothermal technology in Madagascar was again very weak than others countries in Africa, like Kenya and South Africa [5]. The Malagasy government in its new energy policy, should be really developed this sector.

All these above results concerning renewable energy can justify the richness of great island and presence of many investors in the island this last years.

\subsection{Summarize of energy production and consumption}

Tables 3 and 4 show the quantity of energy produced and consumed in Madagascar during these last years.

In Table 3, it is seen that in Madagascar, the energy production increases to $16.7 \%$ from 2005 to 2012 ; and, up to $28.6 \%$ between 2012 and 2018. It is important to notice that, between 2008 and 2018 , the production of renewables and other energies increased up to $28.5 \%$.

In the Table 4, it is observed that between 2005 and 2018, energy consumption has increased to $60.6 \%$. May be, because of the growth of the population.

\subsection{Policy evaluation mechanism}

The Government of Madagascar is implementing a comprehensive program of economic reforms to achieve accelerated economic growth in energy, and to boost the initiative of private investors [14,31and 50].The need for a new energy policy(NEP) comes from challenges left by the reforms of the 1990s and 2000s.After the failure of the approach in the 1970s, by putting the sub-sectors of electricity and hydrocarbons under state monopoly, and forest resources under its centralized administration in the years 1990 and 2000, the government has aimed to promote liberalization and private participation in electricity and hydrocarbons, and partially delegated the management of forest resources to local authorities $[49,56]$. However, the reforms have not yielded the desired results.

The Government now wants to develop a NEP based on a broad consensus achieved through a transparent process of development, which draws its lessons from the previous years.

To better understand this new energy policy, it is important first of all to evaluate the main energy problems encountered, to evaluate some of the country's energy opportunities and, finally, to show the main strategies and new political views of the new government country.

\subsubsection{Energy problem}

The energy sector in Madagascar rests on unsustainable practices that hinder the economic and social development of the country and threaten the local and global environment $[40,48,50]$. Local reserves of hydrocarbon remain untapped, and the country has to import the totality of its needs (about $900,000 \mathrm{~m}^{3}$ of liquid 


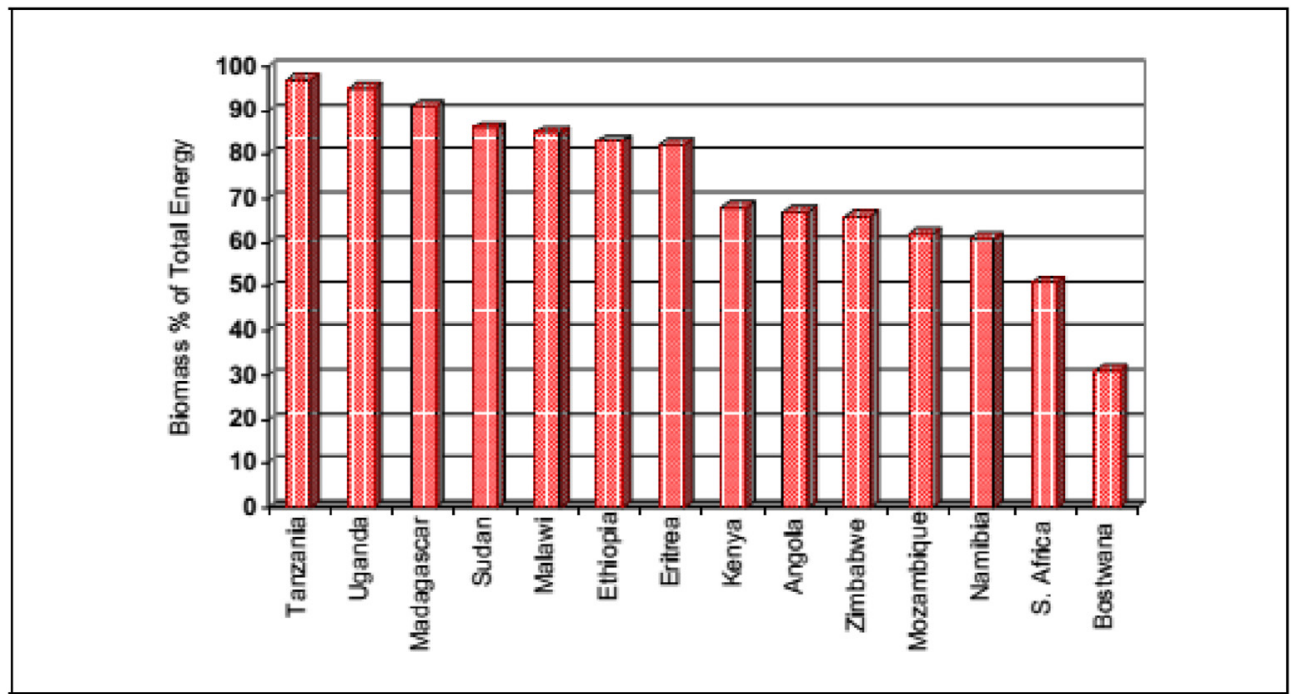

Fig. 8. Percentage of biomass energy in Madagascar compared to other countries in Sub-Saharan Africa [46].

Table 2

Estimation of wood potential production in Madagascar [6].

\begin{tabular}{|c|c|c|c|}
\hline Stratum & Wood - raw energy potential (m3) & Rotation(Year) & Exploitable volume(m3/year) \\
\hline Wet dense forest & $14,297,144$ & 20 & 357,429 \\
\hline Hot dense forest & $18,336,039$ & 20 & 458,401 \\
\hline Thickets & $2,765,051$ & 15 & 92,168 \\
\hline Training with ligneous Elements & $144,164,669$ & 10 & $7,208,233$ \\
\hline Partial total & $179,562,903$ & - & $8,116,231$ \\
\hline Reforestation from energy Vocation & $7,369,453$ & 07 & $1,052,779$ \\
\hline
\end{tabular}

Table 3

Variation of energy production between 2000 and 2018 in Madagascar(EIA,2020).

\begin{tabular}{|c|c|c|c|c|c|c|c|c|c|c|c|c|c|c|}
\hline Year & 2005 & 2006 & 2007 & 2008 & 2009 & 2010 & 2011 & 2012 & 2013 & 2014 & 2015 & 2016 & 2017 & 2018 \\
\hline Total production (quad Btu) & 0.006 & 0.006 & 0.007 & 0.007 & 0.007 & 0.007 & 0.007 & 0.007 & 0.008 & 0.009 & 0.009 & 0.008 & 0.008 & 0.009 \\
\hline $\begin{array}{l}\text { Nuclear, } \\
\text { Renewables \& other (quad Btu) }\end{array}$ & 0.006 & 0.006 & 0.007 & 0.007 & 0.007 & 0.007 & 0.007 & 0.007 & 0.008 & 0.009 & 0.009 & 0.008 & 0.008 & 0.009 \\
\hline Nuclear (quad Btu) & 0 & 0 & 0 & 0 & 0 & 0 & 0 & 0 & 0 & 0 & 0 & 0 & 0 & 0 \\
\hline Renewables and other (quad Btu) & 0.006 & 0.006 & 0.007 & 0.007 & 0.007 & 0.007 & 0.007 & 0.007 & 0.008 & 0.009 & 0.009 & 0.008 & 0.008 & 0.009 \\
\hline
\end{tabular}

Table 4

Variation of energy consumption between 2000 and 2018 in Madagascar (EIA 2020).

\begin{tabular}{|c|c|c|c|c|c|c|c|c|c|c|c|c|c|c|}
\hline Year & 2005 & 2006 & 2007 & 2008 & 2009 & 2010 & 2011 & 2012 & 2013 & 2014 & 2015 & 2016 & 2017 & 2018 \\
\hline Total consumption (quad Btu) & 0.033 & 0.033 & 0.035 & 0.037 & 0.033 & 0.035 & 0.039 & 0.046 & 0.049 & 0.052 & 0.056 & 0.06 & 0.054 & 0.053 \\
\hline Coal (quad Btu) & - & - & - & - & - & 0.001 & 0.003 & 0.006 & 0.01 & 0.009 & 0.008 & 0.009 & 0.011 & 0.01 \\
\hline $\begin{array}{l}\text { Natural } \\
\text { Gas (quad Btu) }\end{array}$ & - & - & - & - & - & - & - & - & - & - & - & - & - & - \\
\hline Petroleum and other liquids (quad Btu) & 0.027 & 0.026 & 0.028 & 0.03 & 0.025 & 0.027 & 0.029 & 0.033 & 0.032 & 0.035 & 0.039 & 0.043 & 0.036 & 0.032 \\
\hline $\begin{array}{l}\text { Nuclear, } \\
\text { Renewables \& other (quad Btu) }\end{array}$ & 0.006 & 0.006 & 0.007 & 0.007 & 0.007 & 0.007 & 0.007 & 0.007 & 0.008 & 0.009 & 0.009 & 008 & 0.008 & 0.009 \\
\hline Nuclear (quad Btu) & 0 & 0 & 0 & 0 & 0 & 0 & 0 & 0 & 0 & 0 & 0 & 0 & 0 & 0 \\
\hline Renewables and other (quad Btu) & 0.006 & 0.006 & 0.007 & 0.007 & 0.007 & 0.007 & 0.007 & 0.007 & 0.008 & 0.009 & 0.009 & 0.008 & 0.008 & 0.009 \\
\hline
\end{tabular}

petroleum products, and 12,000 tons of gas in 2012), which threatens the security of supply and entails high costs $[13,56]$. Paraffin is used for lighting by three-quarters of the population, and fossil fuels are subject to inefficient consumption by businesses and industries [6].The electrical service is inefficiency [2,4and 13] and it remains dominated by electricity distribution company(Jirama) whose losses amount to 35\% [6].The quality of service does not conform to the desired standards. This is also subject to inadequate rates for covering operational costs, leaving little to invest in maintenance or expansion [4].

Despite numerous efforts, forest resources (which provide $90 \%$ of the energy consumed in the country) are exploited in an unsustainable manner, which includes destruction of natural forests ( $10 \%$ of forest has been lost in the last 20 years, with a risk of losing up to $24 \%$ by 2030 , this rate was estimated at $8 \%$ for all of Madagascar [26-29]. Improved stoves are rarely used, and cooking is highly inefficient, with much risk to safety and health. 


\subsubsection{Energy opportunities}

Great opportunities exist to make it an efficient and sustainable sector, but sadly, remain unrealized. The country has untapped conventional oil and unconventional resources, natural gas and coal still left to be exploited, which can reduce hydrocarbon import $[27,31]$.

The utilization of the abundance of renewable resources can reduce the operating costs and the import costs of hydrocarbons incurred by Madagascar [62-66].

The hydroelectric potential in large and small scale is almost $8000 \mathrm{MW}$, distributed in the entire country, facing a current available capacity of approximately $350 \mathrm{MW}$ [6].Madagascar has the highest potential for hydroelectric power among all places in Africa, but it has not been sufficiently exploited. One thousand five hundred sites spread all over the country have been identified and are in various stages of study [7].

- The agricultural biomass resources (rice husk, sugarcane) and organic and solid waste, can fuel power generation.

- Some sites exist that are economically viable for operation by wind power.

- Ocean energy and geothermal resources also have a potential that can be explored in future. Access to electricity and increasing lighting can be achieved in an economical manner through a combination of network extension mainly with hydroelectric power generation; hydraulic mini-grids, biogas, solar/wind, diesel, solar lights and solar home systems investments in the existing networks can provide operational and financial viability of the electricity services [36-38]. Replacing carbonization millstones and traditional homes with high-efficiency equipment can reduce deforestation and save money both for producers and households. The potential for efficient and economic use of energy is important for both electricity from thermal use of fossil fuels and from biomass.

\subsubsection{Strategies and vision of the NEP}

\section{(i) Energy strategies}

The strategy for implementation of the NEP in Madagascar is oriented with three subsectors, namely biomass, electricity and hydrocarbons [7].Table 3 shows the different bases of foundation and the principles.

\section{(ii) Energy vision}

The vision of the NEP is to overcome the obstacles to the full realization of these opportunities, in order to establish an energy sector that promotes the prosperity and well-being of the citizens, and promotes the country's economic development [6].The production, operation and use of resources that are based on sustainable practices, guarantee the energy security of the country $[4,7]$.The vision has five qualitative goals: universal access to modern energy, affordability of price, quality and service reliability, energy security and sustainability. Each of these objectives is to be achieved at the least cost, taking into account the economic and social benefits of the country [56].Achieving an energy matrix in 2030 that meets this vision represents an opportunity (and challenge) of investment to the tune of USD 13 billion, but the benefits would be three times more than the costs, and that should save 158 million tons of $\mathrm{CO}_{2}$ over the next 15 years [4].The indicative quantitative targets defined during extensive consultation scan translate the effort of the government in the fundamental energy needs of Malagasy, in cooking, lighting and electricity, and commercial, thermal and industrial uses. These objectives are part of the framework of "Sustainable Energy for All", for universal access to modern energy and a doubling of renewable penetration and energy efficiency at the global level by 2030 . With regard to the development of the types of power plants in 2030, electricity production will come from $75 \%$ hydropower, $5 \%$ wind power and $5 \%$ solar power, that is, $85 \%$ from clean energy sources, and the remaining $15 \%$ being thermal power and the supporting of renewable energy [7].Support programs for information on access to appropriate technologies will be conducted. The objectives of the Madagascar policy are not definitive. They must, instead, guide the implementation of the Policy, which will help conduct specific studies to further clarify its qualities objectives and the principle of less cost [14,25,28,31and56]:

Cooking - At present, $71 \%$ of the households live in modern homes, against about 4\% (70\% improved stoves for wood or coal, and about $1.5 \%$ of liquefied petroleum gas and ethanol). One hundred percent sustainably sourced wood is turned into charcoal, with the help of a millstone, in high-efficiency carbonization.

Electricity and lighting - Seventy percent of the households will have access to electricity or sources of modern lighting as against $15 \%$ at present. This will be achieved by an extension of $70 \%$ of the interconnected network (with a generation mix of $75 \%$ hydro and $15 \%$ thermal, to be defined according to the local hydrocarbon development, $5 \%$ wind and 5\% solar power); $20 \%$ of the mininetworks (with a mixed production of $50 \%$ hydro, $20 \%$ biogas from rice husks, $25 \%$ diesel and 5\% solar); $5 \%$ SSD and 5\% sunlamps. In total, $80 \%$ of the energy requirement projected for 2030 will be from renewable sources. Sixty percent of households, businesses and industries will adopt the efficiency measures of electric consumption, against a rate of almost non-existent penetration right now.

Thermal, commercial and industrial use -Sixty percent of businesses and industries will adopt effective measures of hydrocarbon and biomass consumption against a penetration rate that is almost non-existent now. The institutional framework required to achieve this vision must be strengthened, must ensure effective coordination between the various entities involved, and must be based on close cooperation with the technical and financial

Table 5

Energy strategies [7]

\begin{tabular}{|c|c|c|}
\hline Axes & Strategies & Principles \\
\hline 1 & - Valuation of natural capital & To build sustainable management of the wood energy \\
\hline & Environment preservation & Define better regulation circuit marketing \\
\hline 2 & $\begin{array}{l}\text { - Access to sustainable energy constantly networks The development of an } \\
\text { electrification plan }\end{array}$ & $\begin{array}{l}\text { - Creation and expansion of inter-regional } \\
\text { - Integrated renewable energy development combination of different } \\
\text { technologies and systems }\end{array}$ \\
\hline 3 & Assurance of security and independence of country's energy & $\begin{array}{l}\text { - Diversification of a mix of energies- Reducing oil imports, } \\
\text { - Exploitation of local energy resources }\end{array}$ \\
\hline 4 & $\begin{array}{l}\text { - Strengthening the regulatory framework and institutional and business } \\
\text { environment }\end{array}$ & - Ensure effective coordination between the various entities involved \\
\hline 5 & Finance the energy needs sustainability & - Rationalisation of the public budget by assigning a lot to this sector \\
\hline
\end{tabular}




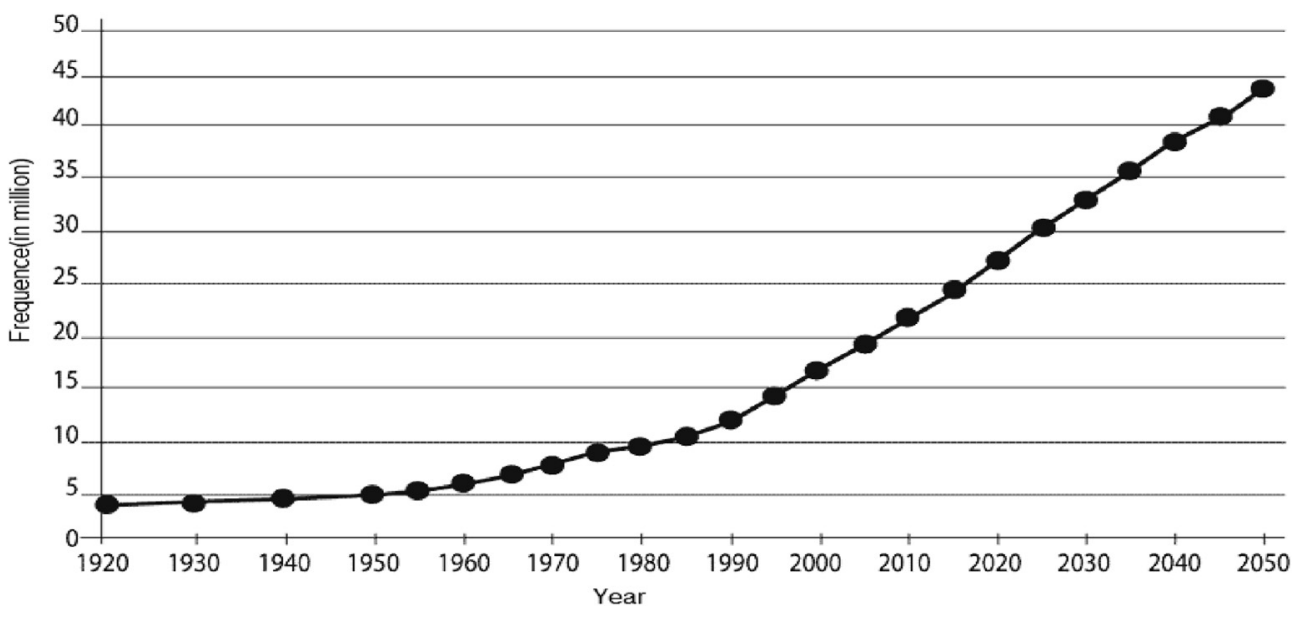

Fig. 9. Variation of population of Madagascar from 1920 to 2050.

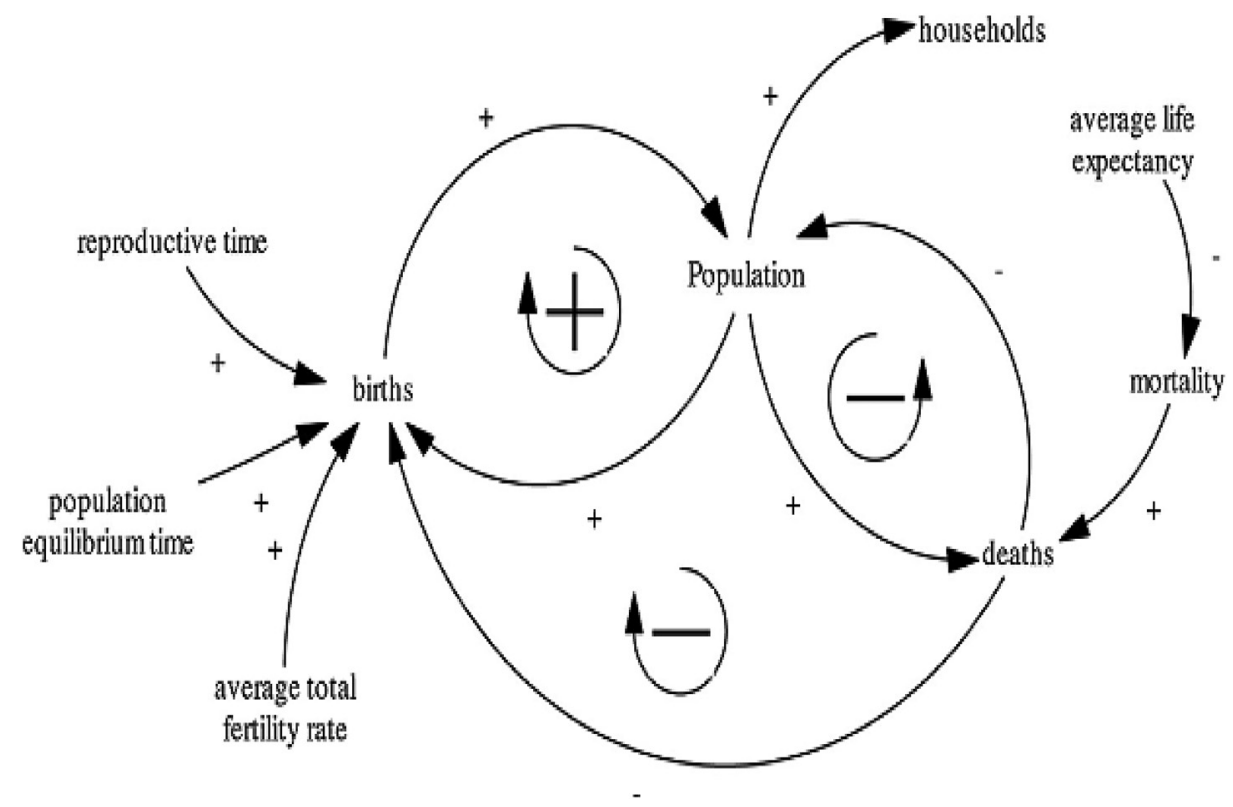

Fig. 10. CLD for population/household module [47].

partners, and private investors.

This includes:

- Increase in skilled human resources in the Ministry of Energy and Hydrocarbons (MEH), so that they can lead the implementation of the Policy.

- Strengthen the capacity and resources of the Development Agency for Rural Electrification (ADER), and Office of Rural of Electrification (ORE),as needed.

- Create a framework for coordination of operations between $\mathrm{MEH}$, the Presidency, the eight ministries involved in the implementation of energy policies (e.g., with regard to water or land), agencies related and under supervision (the Office of Rural of Electrification, ADER, Jirama, the Malagasy Hydrocarbons Office) and the civil society.

Make permanent the committees set up for the development of this Policy: establish a concrete dialogue with donors and private investors who are planning interventions to achieve this, based on the implementation plan of this Policy. (iii) Energy Sector Governance

The main statements adopted for the NEP are as follows [2,6and35]the 98-032 Law of January 20, 1999, relating to the Electricity Sector Reform; the Political Declaration of 1999 which confirms the principles of liberalization of the subsectors of electricity and hydrocarbons; the law 2002-001 of 7 October, 2002: relative to the creation of the National Electricity Fund. The Decree 2001-173 of 28 February 2001: laying down the conditions and procedures for implementing Law No. 98-032 of January 20, 1999, on the reform of the electricity sector; the Decree 2001-803 of September 19, 2001 and 2003-194 of March 4, 2003: stating the organization and functioning of the ORE Decree of 2003-804 of July 16, 2003: appointing members of the Board of Electricity of the ORE; the decree 2004-013 of January 7, 2004: appointing the Chairman of Electricity for the ORE; the Order No. 3910/2009-MdE, of June 17, 2009: carrying terms of adjustment of electricity rates for sale; Decree 2005-1055 of March 14, 2005: fixing the rate of a percentage for permittees' turnover and dealers in the electric power sector; the National Policy of the 2005 basic Energy Action 


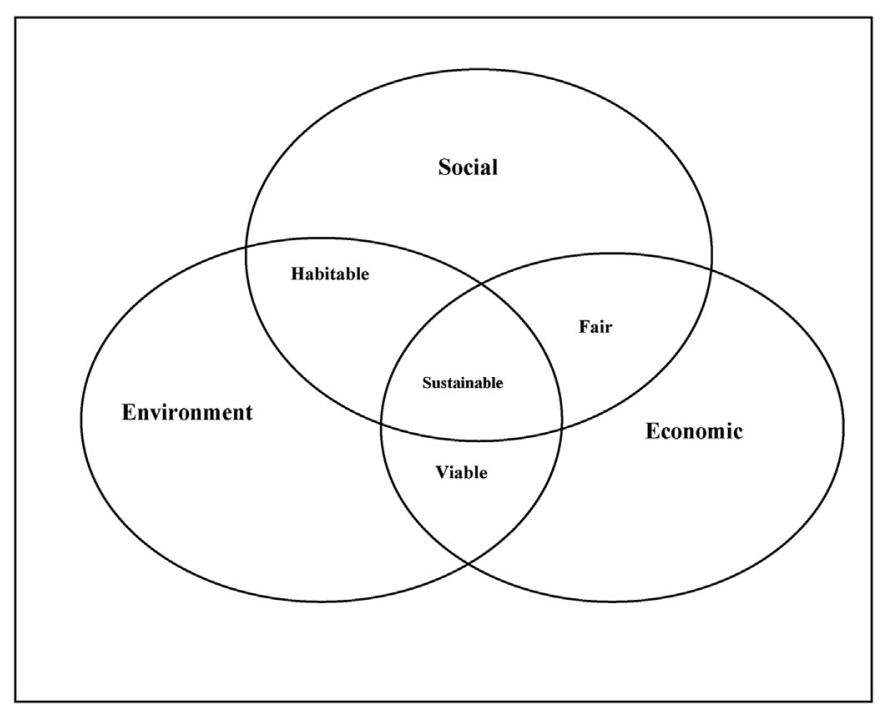

Fig. 11. Vision of Sustainable development.

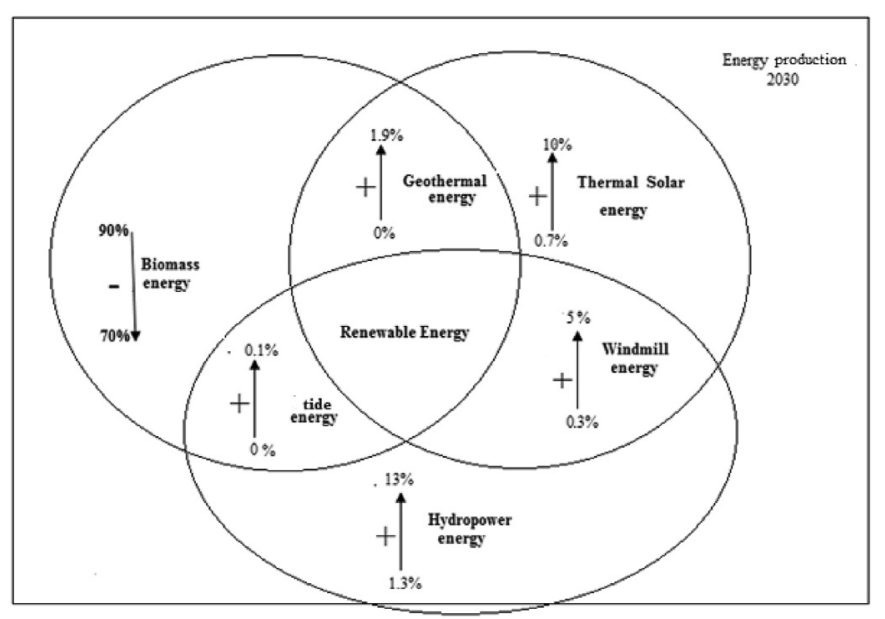

Fig. 12. The renewable energy sector and vision 2030 .

Plan of Madagascar or MAP 2007-2012 energy; the Sector Policy Letter of Water and Electricity 2007; the law 2015-003 bearing of the Discounted Environmental Malagasy Charter; the 2010 Climate Change Policy; the document of the National Policy of Framework Mining and Petroleum of 2014. Other strategies are given in the Table 5.

The next section gives in detail some visions of the Madagascar to reach emergence in 2030.

\subsection{A vision of the country towards emergence in 2030; a retroactive code}

\subsubsection{Development based on strong population growth}

The current population of Madagascar Island is around of 27M. Fig. 9 shows the variation of the population with an annual growth rate around of $3 \%$.

Madagascar, for its emergence, should be able to reach the annual growth rate of $5 \%$ by 2030 .Therefore, its population will be estimated at 36,235,340 in the same year. A large workforce could be a major force for the development of Madagascar. For this reason, Motawa and Oladokun [47], have suggested a causal loop diagram(CLD) module for the population, as shown in Fig. 10. This figure shows a combination of positive and negative loops involving some of the variables hypothesized to drive the population, and hence, households. The positive loop, according to Motawa and Oladokun [47], could be read as "the more the people, the more the births there will be; the more births there are, the more people there will be". Alternatively, this could be read as "the fewer people there are, the fewer births there will be; the fewer births there are, the fewer people there will be". The number of births is also based on the reproductive time, population equilibrium time, and average total fertility rate. The positive or reinforcing feedback shows that the population will continue to grow or decline as births continue to grow or decline, respectively. However, the two negative or balancing loops involving population deaths and population deaths births will act to stabilize and balance the system from continual increment or decrement. It is evident, that average life expectancy drives mortality, and mortality in turn drives death. The expected behavior of the output of this module will be based on the interaction of these multi-loops. Some of the loops may be dominant. For example, if the positive loop is a dominant one, it may mean that the population will continue to grow, although the rate of growth may vary. However, if the negative loops are the dominant ones, then deaths will continue to grow, and theoretically, the population may decline until such time that the total population will go into extinction and there will be no more households.

\subsubsection{Sustainable development}

Fig. 11 shows the different aspects for the sustainable development of Madagascar. In fact, sustainable development is a political strategy, which has the aim to assure the continuity of economic and social development with respect to environment, and not to compromise the capacity of future generations to answer for themselves to answer as "Habitable" for the social environment, "Fair" for the social and economic conditions, and finally, "Viable" for the economic environment.

Madagascar should insist on the development of renewable energy for it emergence in 2030.In this sense, the ministry of energy explained that, energy policy for 2015-2030 in Madagascar, addresses several pressing economic, social, and environmental challenges. It supports the transition to the energy mix for electricity and lighting, which will include $80 \%$ of renewable resources, to achieve the goal of providing electricity to $70 \%$ of the population.

In Fig. 12, the positive arrow could be read as "an enhancement of production", and the negative arrow as "a loss of production". At present, 90\% of the energy produced in Madagascar comes from "biomass energy", which should decrease up to $70 \%$ in 2030 . Hydropower energy will produce $13 \%$ of the total energy in 2030 . In addition, wind turbine energy, thermal-solar energy and geothermal energy will be between $0.3 \%$ and $5 \%, 0.7 \%$ and $10 \%$, and $0 \%-1.9 \%$, respectively. Only $0.1 \%$ will come from tidal energy. Those minimum needs correspond to an equivalent of around $50 \mathrm{~kg}$ of petroleum as yearly trading energy per head of inhabitant. Fig. 13a, b and 13c, show a code to develop and improve the production of biomass, electricity and hydrocarbon energies. The NEP of Madagascar is essentially oriented on these three sectors. The main biomass energy strategies are "protection of forest resources", "reforestation of 35,000-40,000 ha per year", and "financing" (see Fig. (13a)). There must then be a direct involvement of the population in the management of financing, collaboration between the energy ministry and other ministries, and practical for energy efficiency. The main objective of Madagascar with regard to electricity will be "to produce $7900 \mathrm{GWh}$ " in 2030 , as opposed to the 1500 GWh currently produced. To that effect, as shown in Figure (13b), Madagascar should develop a mini-system, utilization of technologies with weak electric consumption, and so on. 
(A)

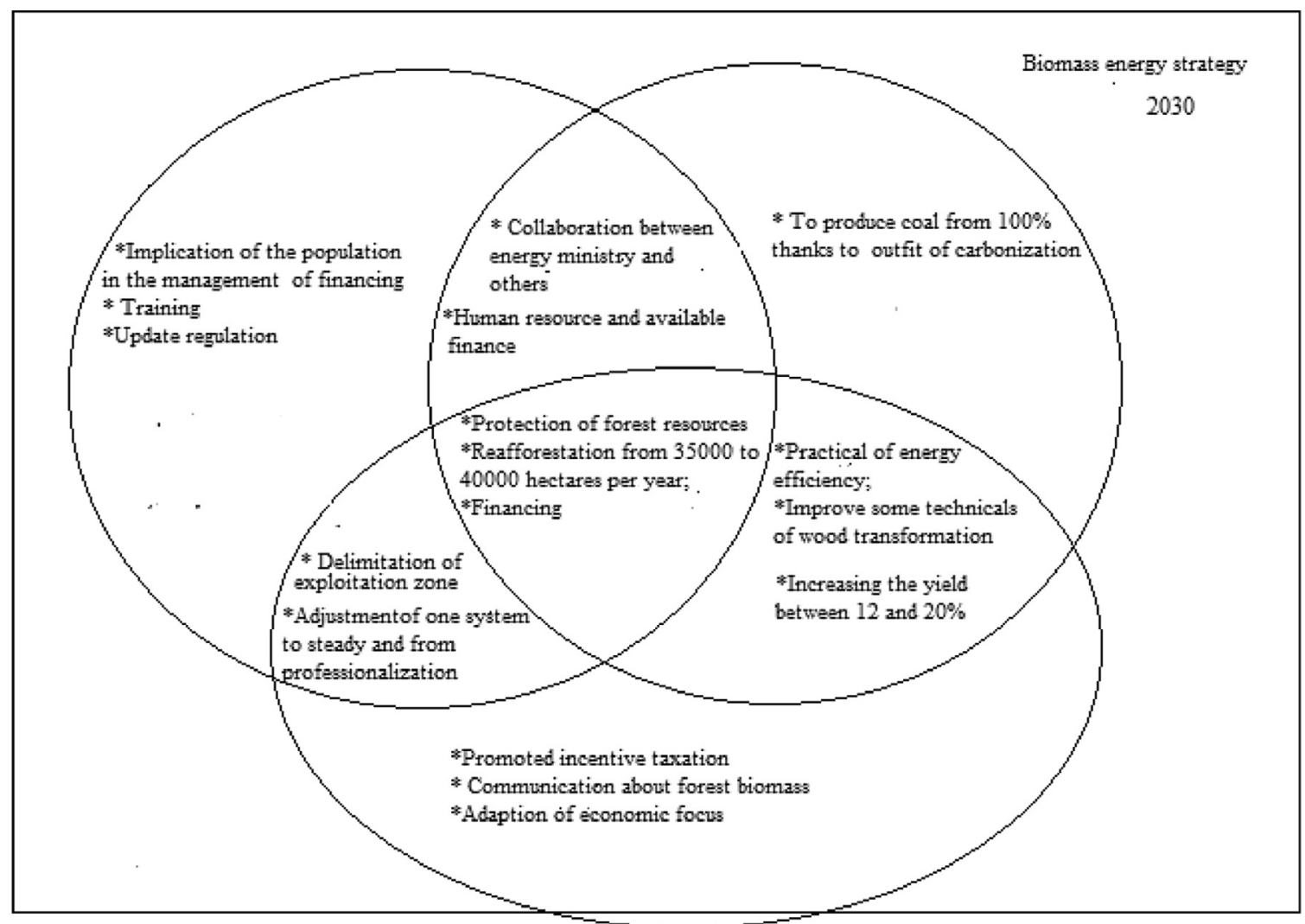

Fig. 13a. A code to develop and to improve the production of biomass energy in the future (2030).

(B)

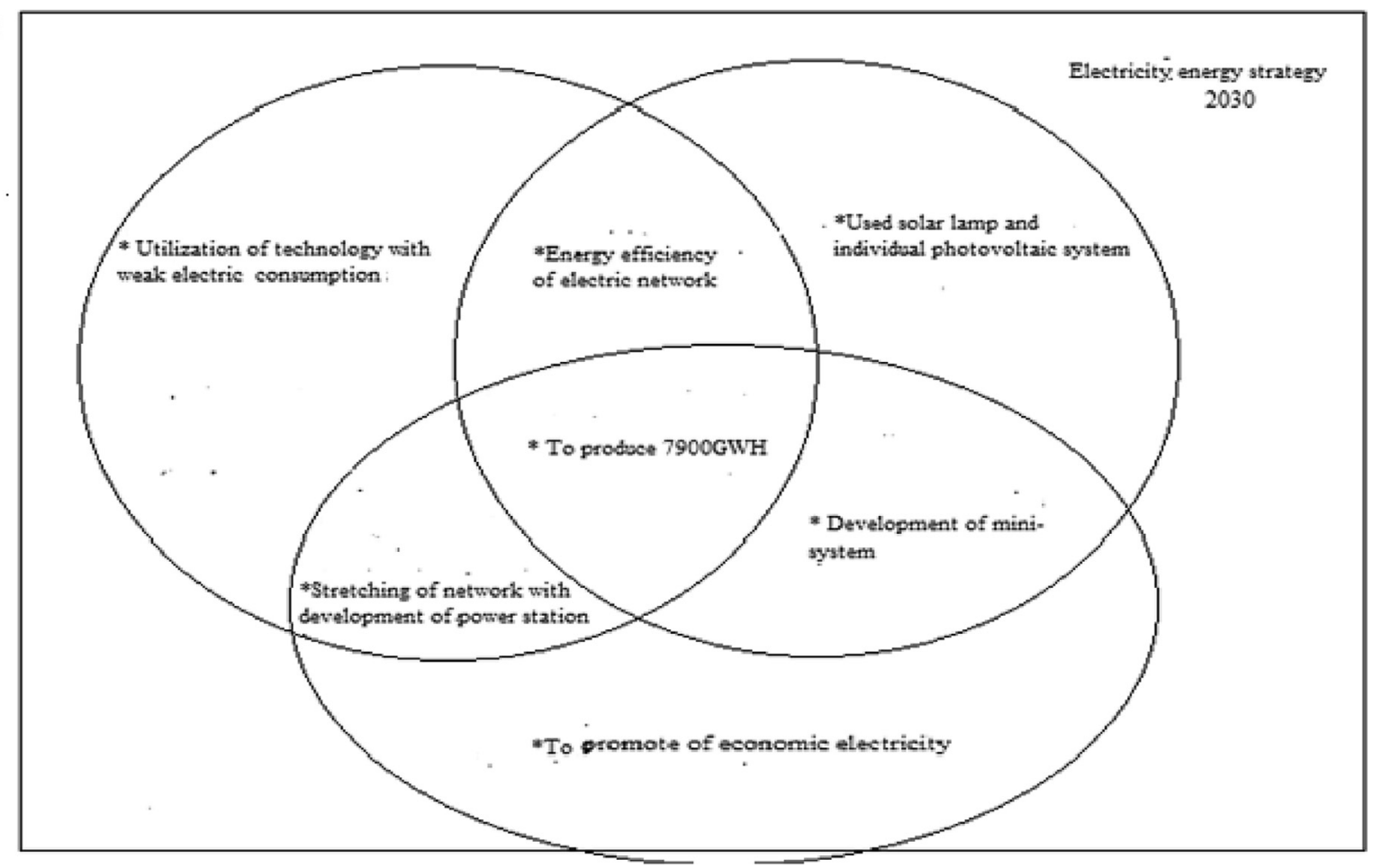

Fig. 13b. A code to develop and improve the production of electricity in the future (2030).

Madagascar is not a great producer of petroleum, hence, to achieve this, its main objective must be to conduct many studies to assess new sites of oil reserves. The simulation details of the direct irradiation in Madagascar are given in section 5. 


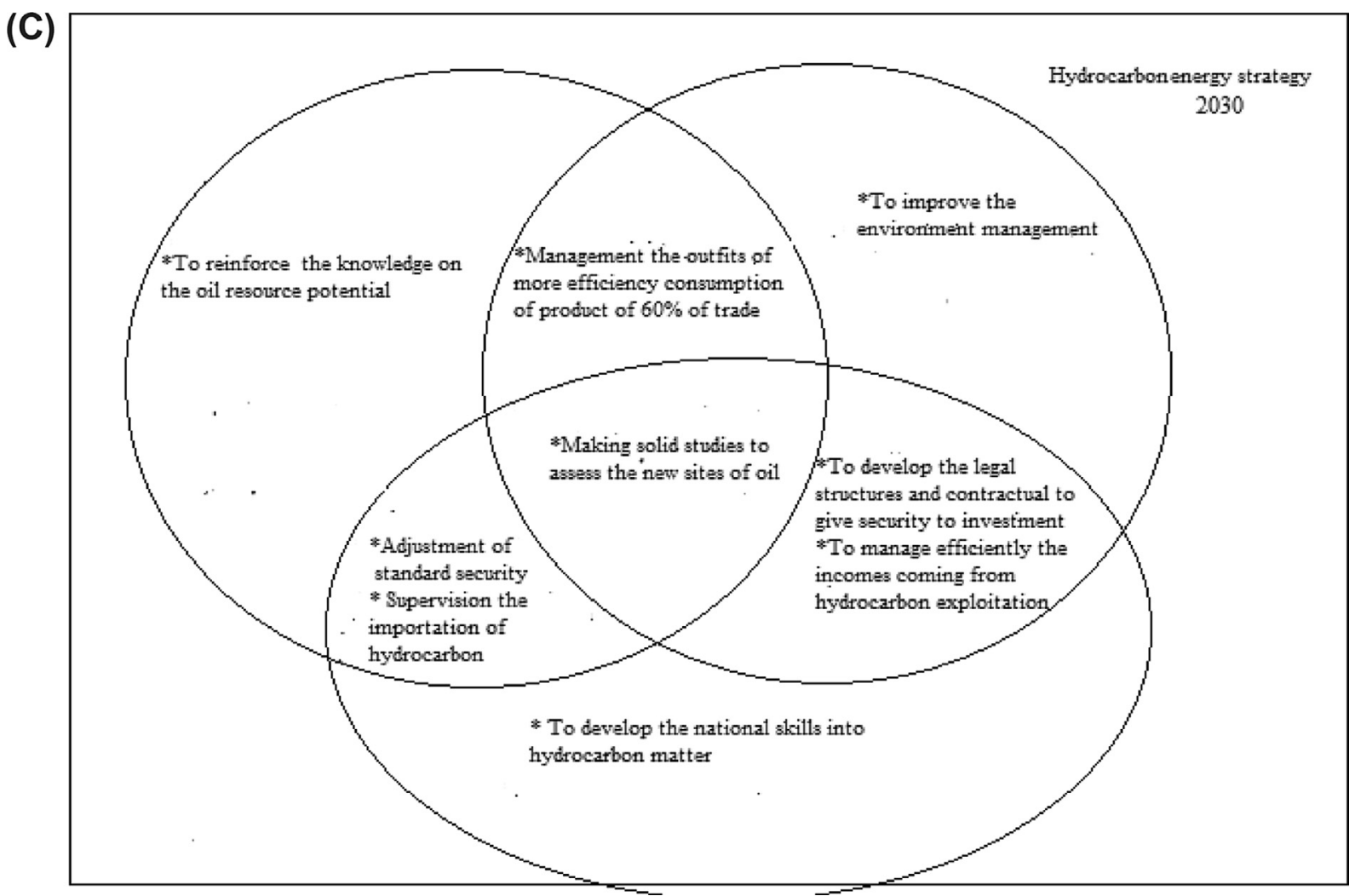

Fig. 13c. A code to develop and improve the production of hydrocarbon energy in the future (2030).

Table 6

Geographical coordinates of the different studied cities.

\begin{tabular}{lllll}
\hline Cities & Latitude & Longitude & Altitude $(\mathrm{m})$ & Area of region $\left(\mathrm{km}^{2}\right)$ \\
\hline Maintirano & $22^{\circ} 01^{\prime} \mathrm{S}$ & $44^{\circ} 22^{\prime} \mathrm{E}$ & 23 & 38,852 \\
Morondava & $20^{\circ} 17^{\prime} \mathrm{S}$ & $44^{\circ} 19^{\prime} \mathrm{E}$ & 08 & 46,121 \\
Toliary & $23^{\circ} 21^{\prime} \mathrm{S}$ & $43^{\circ} 40^{\prime} \mathrm{E}$ & 11 & 16,140 \\
Fort-dauphin & $25^{\circ} 02^{\prime} \mathrm{S}$ & $46^{\circ} 68^{\prime} \mathrm{E}$ & 08 & 25,731 \\
Fianarantsoa & $21^{\circ} 27^{\prime} \mathrm{S}$ & $47^{\circ} 05^{\prime} \mathrm{E}$ & 1115 & 87 (district) \\
Ambositra & $20^{\circ} 31^{\prime} \mathrm{S}$ & $47^{\circ} 14^{\prime} \mathrm{E}$ & 1280 & 3199 \\
Antsirabé & $19^{\circ} 51^{\prime} \mathrm{S}$ & $47^{\circ} 02 \mathrm{E}$ & 1500 & 16,599 \\
Antananarivo & $18^{\circ} 54^{\prime} \mathrm{S}$ & $47^{\circ} 32^{\prime} \mathrm{E}$ & 1276 & 88 (district) \\
Toamasina & $18^{\circ} 09^{\prime} \mathrm{S}$ & $49^{\circ} 24^{\prime} \mathrm{E}$ & 06 & 20 (district) \\
Maroantsetra & $15^{\circ} 26^{\prime} \mathrm{S}$ & $49^{\circ} 44^{\prime} \mathrm{E}$ & 10 & 21,930 \\
Sainte-Marie & $14^{\circ} 47^{\prime} \mathrm{N}$ & $60^{\circ} 59^{\prime} \mathrm{O}$ & 767 & 200 \\
\hline
\end{tabular}

\section{Study of direct irradiation in some regions of Madagascar}

The purpose of this sub-paragraph is to carry out an analysis of the variation in the direct radiation obtained by simulation in a few cities of Madagascar. This study will allow us to have an estimation on the solar deposit in Madagascar.

\subsection{Method and data acquisition}

A comparison between the measured data and simulated direct radiation is not yet possible for all these studied cities, because data for these areas is nonexistent (excepted Antananarivo city). To validate the model, we used to study data from Antananarivo city, were obtained from National Aeronautics and Space Administration(NASA), database for a twenty one year period(1984-2004) [57].All of the data used in this study were subjected to a quality control and relevant statistical tests before applying them to the model. This was done by plotting time variation graph to determine the spurious values.

The geographical locations of the different cities studied are shown in Fig. 1 and Table 6 shows the geographical coordinates of the different cities studied.

\subsubsection{Mathematical modeling}

Mesri et al. [51] studied some theoretical models to estimate the components of solar radiation received at ground level. These models take into account the effects of scattering and absorption of solar radiation during its passage through the atmosphere. The obtained results through simulation showed that the model of Davies \& Hay and this of Bird \& Hulstrom, give better estimate of solar components where errors between the measured values and those calculated are negligible. Staying in his logical, in this study, we have chosen the model of Bird \&Hulstrom [51]. It's actually, the best model for this study. Climatic data were almost similar. The illumination due to direct radiation on a horizontal plane is given in Equation (1):

$\mathrm{I}=0.9751 \times \mathrm{I}_{\mathrm{sc}} \times \tau_{\mathrm{r}} \times \tau_{\mathrm{g}} \times \tau_{0} \times \tau_{\mathrm{w}} \times \tau_{\mathrm{a}} \times \cos \left(\theta_{\mathrm{z}}\right)$

Where the coefficient of absorption by the ozonelayer $\tau 0$ is given in Equation (2): 


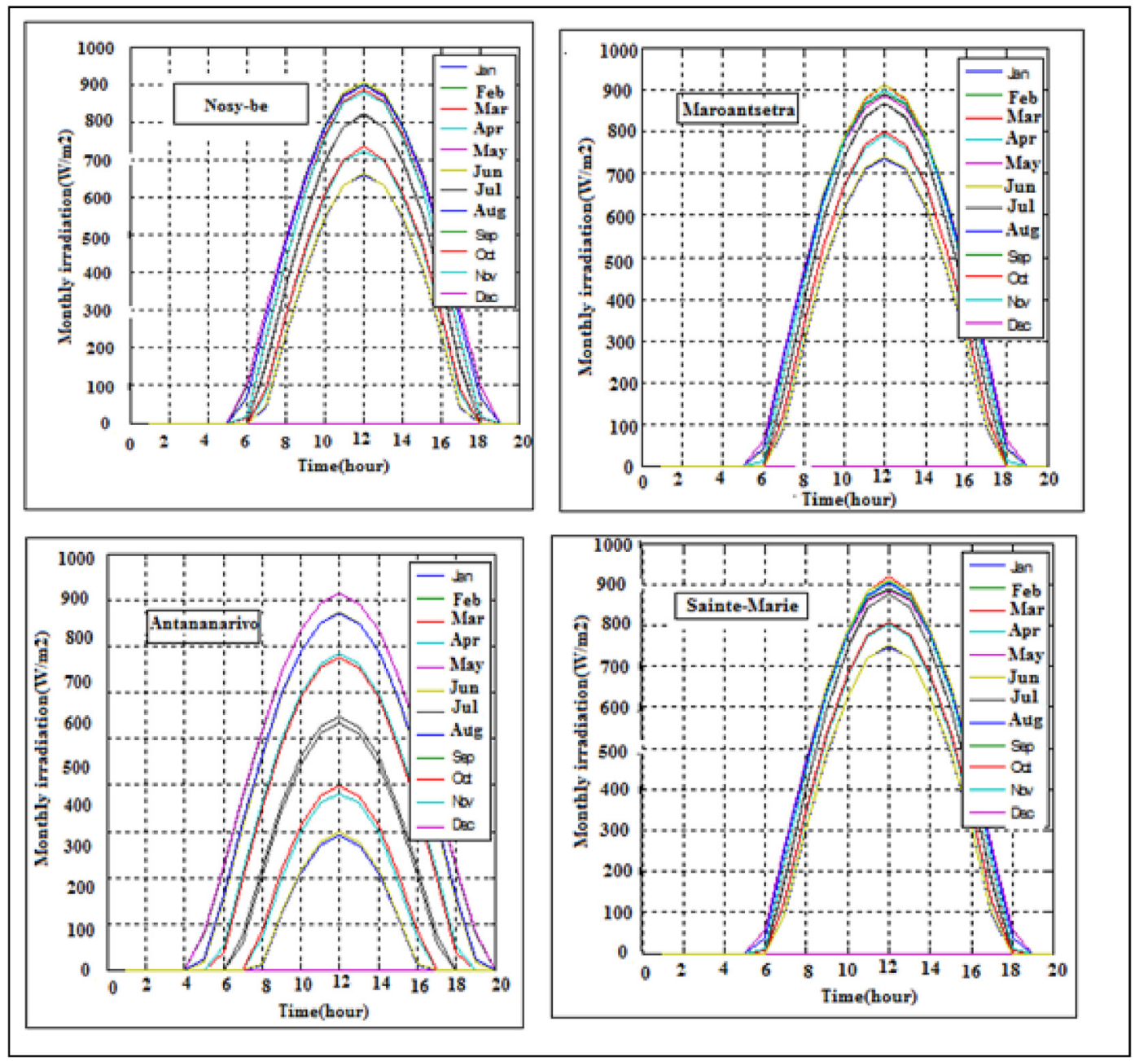

Fig. 14. Monthly irradiation in the regions with a transition tropical climate.

$\tau_{0}=1-0.1611 \times \mathrm{U}_{\mathrm{O}} \times\left(1.0+139.48 \times \mathrm{U}_{\mathrm{O}}\right)^{-0.3035} \times 0.002715 \times \mathrm{Uo} \times\left(1+0.044 \times \mathrm{Uo}+0.0003 \times \mathrm{Uo}^{2}\right)^{-1}$

where Uo is the thickness of the ozone layer corrected by the optical path of the solar radiation through this layer. The transmittance after absorption of solar radiation by water vapor is given in Equation (3):

$\tau_{\omega}=1-2.4959 \times U_{w} \times\left[\left(1+79.03 \times U_{w}\right) 0.6828+6.385 \times U_{w}\right]^{-1}(3)$

where Uw is the thickness of condensable water in the vertical location $(\mathrm{cm})$. The transmittance after absorption by permanent gases $\left(\mathrm{CO}_{2}\right.$ and $\left.\mathrm{O}_{2}\right)$ is expressed as a function of the air mass corrected by using Equation (4):

$\tau_{\mathrm{g}}=\exp \left(-0.0127 \times \mathrm{m}_{\mathrm{a}}^{0.26}\right)$

where $\mathrm{m}$ is the mass of the air corrected.

The transmittance after molecular diffusion is also expressed as a function of the air mass inEquation (5): $\tau_{\mathrm{r}}=\exp \left[-0.0903 \times \mathrm{m}_{\mathrm{a}}^{0.84}\left(1.0+\mathrm{m}_{\mathrm{a}}-\mathrm{m}_{\mathrm{a}}^{1.01}\right)\right]$

and the transmittance after aerosol scattering can be calculated from Equation (6):

$\tau_{\mathrm{a}}=\exp \left[-\mathrm{k}_{\mathrm{a}}^{0.873} \times \mathrm{m}_{\mathrm{a}}^{0.9108} \times\left(1.0+\mathrm{k}_{\mathrm{a}}-\mathrm{k}_{\mathrm{a}}^{0.7088}\right)\right]$

where $\mathrm{k}_{\mathrm{a}}$ was giveninequation(7):

$\mathrm{k}_{\mathrm{a}}=0.2758 \times \mathrm{k}_{\mathrm{a} \lambda} / \lambda=0.38 \mu \mathrm{m}+0.35 \times \mathrm{k}_{\mathrm{a} \lambda} / \lambda=0.5 \mu \mathrm{m}$

$\mathrm{k}_{\mathrm{a} \lambda} / \lambda=0.38 \mu \mathrm{m}$ and $\mathrm{k}_{\mathrm{a} \lambda} / \lambda=0.5 \mu \mathrm{m}$ are two attenuation coefficients determined from experimental measurements derived by Equation (8).

$\mathrm{k}_{\mathrm{a}}(\lambda)=\beta \times \lambda^{-\alpha}$

where, $\alpha$ is the coefficient of particle size distribution and the coefficient $\beta$ disorder established by Angstro. These values have 


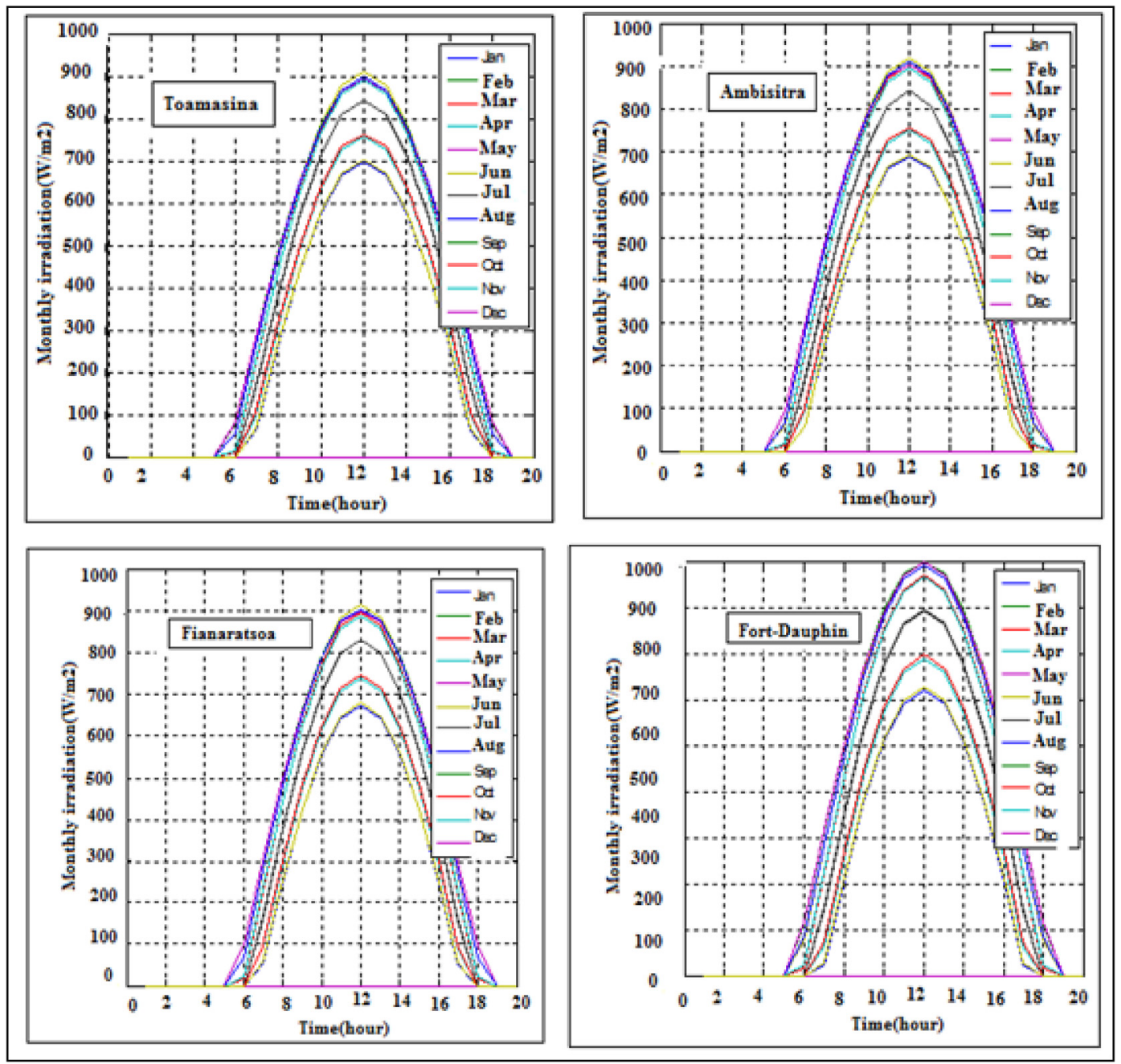

Fig. 15. Monthly irradiation in the regions with a humid tropical climate.

allowed us to calculate $\mathrm{k}_{\mathrm{a} \lambda} / \lambda=0.38 \mu \mathrm{m}$ and $\mathrm{k}_{\mathrm{a} \lambda} / \lambda=0.5 \mu \mathrm{m}$.

\subsubsection{Validation of the model}

The performance of the studied model was tested statistically, thanks to coefficient $\left(R^{2}\right)$. It is a statistical measure that indicates how the straight regression line adjusts the actual data. A values of $\mathrm{R}^{2}$ nearest to 1 , indicates that the straight regression line fits well the data. This indicator varies between 0 and 1 . A value of 1 indicates perfect agreement between measurements and model, while 0 , indicates total disagreement [58].

$R^{2}=1-\frac{\sum_{i=1}^{n}\left(R_{\text {meas }-}^{(i)} R_{\text {Sest }}^{(i)}\right) 2}{\sum_{i=1}^{n}\left(R_{\text {meas }}^{(i)}\right) 2}$

Where $R_{\text {meas }}^{(i)}, R_{\text {Sest }}^{(i)}$ and nare, respectively, the ith measured values and ith estimated values of daily solar radiation and the number of values. All the calculations were performed under the Matlab environment.

\subsection{Results and discussion}

Direct irradiation in14 cities of Madagascar are depicted in Figures 14-16, according to the climate. In Fig. 14, by regrouping four cities, it is shown that direct irradiation is most pronounced in
"Maroantsetra", with an average yearly irradiation of around $850 \mathrm{~W} / \mathrm{m}^{2}$.It is least hot in "Antananarovo". The monthly gap of irradiation is really important in this town, as it fluctuates greatly in humidity, and has weak wind speed throughout the year. However, in all these cities, the maximal direct irradiation is around 900W/ $\mathrm{m}^{2}$.June and August are the least sunny months in "Antananarivo", with $300 \mathrm{~W} / \mathrm{m}^{2}$ being the maximum irradiation. In" Fort-Dauphin" which has a humid tropical climate(see Fig. 16) and an outdoor air temperature between $18{ }^{\circ} \mathrm{C}$ and $34^{\circ} \mathrm{C}$, direct irradiation is very significant (around $1000 \mathrm{~W} / \mathrm{m}^{2}$ ), as compared to the three other cities. It is the hottest in "Toamasina" (alt $=6 \mathrm{~m}$ ) and "FortDauphin" (alt $=8 \mathrm{~m}$ ) compared to "Ambisitra" (alt $=1280 \mathrm{~m}$ ) and "Fianarantsoa"(alt $=1115 \mathrm{~m})$, perhaps because of the differences in altitudes [52]. In fact, the closer we move from the coastal region to the mountainous region, the air temperature decreases [45].

Meanwhile, minimum irradiation is obtained in June in these different cities. Irradiation is often very unstable in "Antananarivo", although it can be saved. There are many cyclones of weak intensity. Monthly irradiation in regions with a hot tropical climate is given in Fig. 15. For the air temperature between $22^{\circ} \mathrm{C}$ and $40{ }^{\circ} \mathrm{C}$, maximum direct irradiation was obtained in "Antsirabe" (935W/ $\mathrm{m}^{2}$ ).In these towns, it was very hot in "August" compared to other months.

The results found in this study with regard to the variation in direct irradiation are in clear agreementas those found by Kameni 


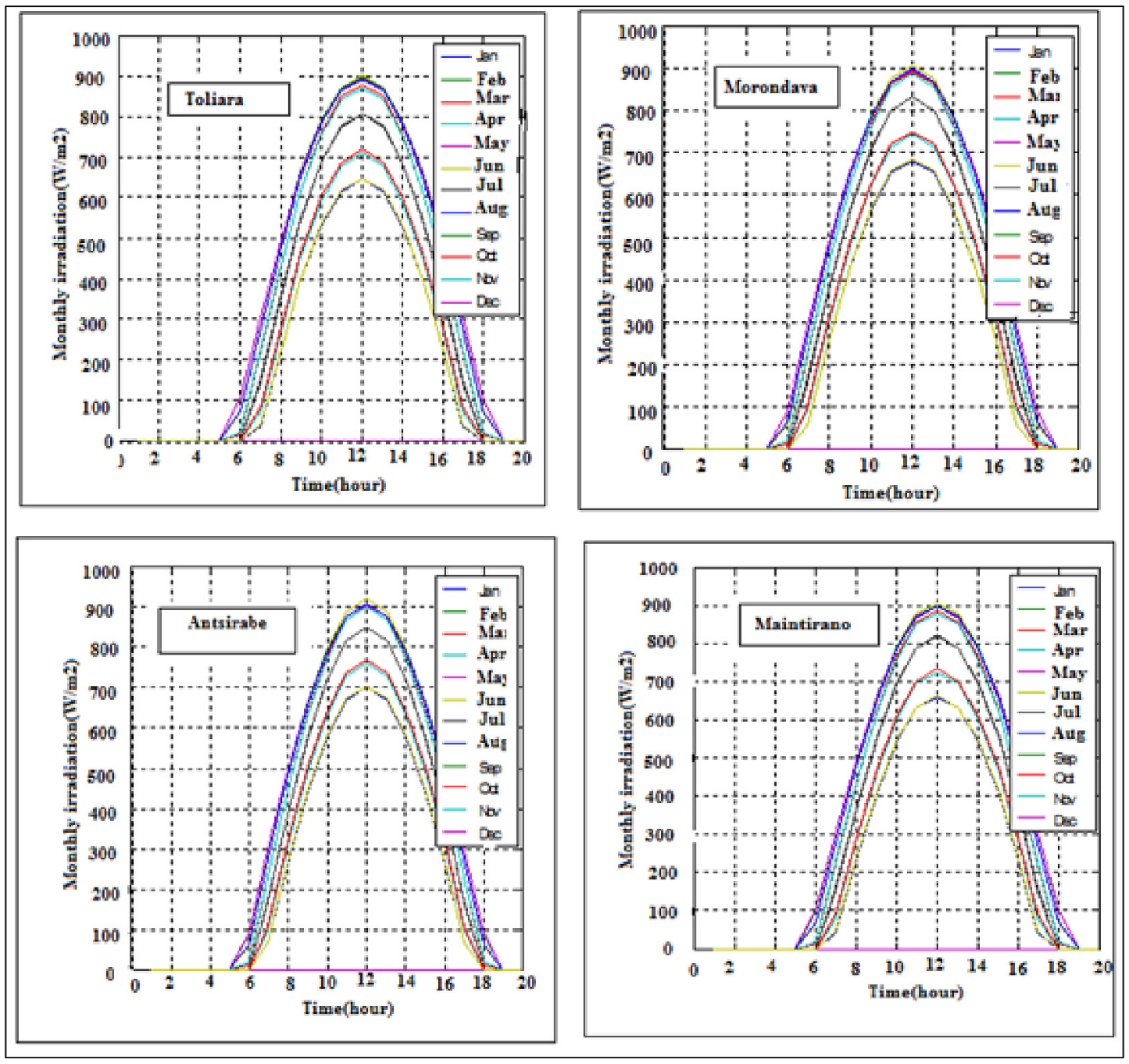

Fig. 16. Monthly irradiation in the regions with a hot tropical climate.

et al. [53].During the entire month, the irradiation peaks to its maximum around midday, but after this time, it decreases up to $6.00 \mathrm{pm}$. From $6.00 \mathrm{pm}$ up to $6.00 \mathrm{am}$, the direct irradiation is null. In this interval of time, the rate of relative humidity increases, while outdoors, the air temperature decreases slightly. The quantity of precipitation is very meager in "Antsirabe", and the heat is intense, which may be as a consequence of climate change.

Finally, despite the observed lateness in energy field, the government developed in the aim to improve the energy potential of country. Some of them are showed in the following paragraph.

Previous section evaluated the irradiation potential in some cities in Madagascar. Indeed, it was seen a strong increase of the utilization of solar panel in the most of regions of country. The new energy policy should be have a significant impact on the energy production in Madagascar in the next few years.

\section{Conclusion}

In this paper, we have made a brief review of the resource potential and new energy policies in Madagascar. We have also suggested some solutions to sustainable support the government in its policy. Madagascar, like many others countries in Sub-Saharan Africa has huge potential resources in renewable energy. Nowadays, less than $5 \%$ of these resources are exploited, perhaps at cause of the bad government's energy policy. In Madagascar, solar potential was estimated to be around $2,000 \mathrm{kWh} / \mathrm{m}^{2} /$ year, exploited at less of
$3 \%$; only $1.3 \%$ of its hydroelectric potential was exploited; wind power potential was estimated over 2,000 MW and exploited at less of $5 \%$. The deforestation continued to act on the climate of country; today, only $20 \%$ of the territory is covered by forest. This problem was the main concern of many international organizations. Thanks to the Government's efforts, an NEP has been established to develop its economy. This new Policy is oriented towards the development of key sectors such as, hydrocarbon, electricity and biomass. An effort should be made by the government to develop renewable energy up to $30 \%$ by 2030 . In this sense, a transition between fossil energies and progressive renewable energies is provided in the new Policy. To consistently advance the energy sector in Madagascar, it is vital to have the complete and total involvement of all stakeholders in the sector with other development partners, such as donors, and also local and foreign investors. Above all, we must encourage the involvement of the population and set a positive image of renewable in the minds of people through awareness campaigns and advertising. This new orientation of the Malagasy Government, vis-à-vis its economy, can be seen as a hope for Africa's future.

\section{Author statement}

All the co-authors of this article contributed to the writing of this research. 


\section{Declaration of competing interest}

The authors declare that they have no known competing financial interests or personal relationships that could have appeared to influence the work reported in this paper.

\section{References}

[1] M. Lalaine, N. Nandrasana, La placedes énergies renouvelables à Madagascar: quelle option de développement pour le pays, Mémoire de Maitrise esSciences Economiques 1 (85) (2014).

[2] K. Nematchoua Modeste, B. Mempouo, T. René, Ángel M. Costa, José A. Orosa, Chrysostôme R.R. Raminosoa, Ramaroson Mamiharijaona, Resource potential and energy efficiency in the buildings of Cameroon: a Review, Renew. Sustain. Energy Rev. 50 (2015) 835-846.

[3] M. Maldague, Politique énergétique intégrée en République Démocratique du Congo, Leçon publique donnée à l'occasion de l'inauguration solennelle de l'Académie 1 (35) (2001). http://www.uqac.ca/jmt-sociologue/.

[4] Rapport de Diagnostic du Secteur Energie à Madagascar, Cabinet AIDES, 2019, 10(45).

[5] S. Karekezi, T. Ranja, Renewable Energy Technologies in Africa, ZED Books and AFREPREN, Oxford, U.K, 1997, 1(12).

[6] Document d'Etude de la Politique et Stratégie de l'Energie, Phases 2 et 3.euei, $2015,1(234)$

[7] Lettre de politique de l'énergie de Madagascar, MINEH 1 (32) (2015-2030).

[8] A. Siddiqi, L.D. Anadon, The waterenergy nexus in Middle East and North Africa, Energy Pol. 39 (8) (2011) 452, 494.

[9] M. Bazilian, H. Rogner, M. Howells, S. Hermann, D. Arent, D. Gielen, P. Steduto, A. Mueller, P. Komor, R.S.J. Tol, K.K. Yumkella, Considering the energy, water and food nexus: towards an integrated modelling approach, Energy Pol. 896 (2011) 906.

[10] A. Aissaoui, MENA Energy Investment Outlook: Capturing the Full Scope and Scale of the Power Sector, vol. 7, 2012. No 10. [Online], Available at: http:// www.apic.com/Research/Commentaries/Commentary_ V07_N10_Oct2012. pdf. (Accessed 21 July 2013).

[11] K. Hussey, J. Pittock, The energy and water nexus: managing the links between Energy and water for a sustainable future, Ecol. Soc. 17 (1) (2012) 31.

[12] P. Nejat, F. Jomehzadeh, M.M. Taheri, M. Gohari, M.Z.A. Majid, A global review of energy consumption, $\mathrm{CO}_{2}$ emissions and policy in the residential sector (with an overview of the top ten $\mathrm{CO}_{2}$ emitting countries), Renewable andSustainableEnergy Reviewer 43 (2015) 843-862.

[13] A.M.T. Randrianarisoa, Réalisation et Publication Friedrich-Ebert-Stiftung. Energie Durable pour Tous, les ménages, les collectivités et les entreprises, Antananarivo, 2013.

[14] Rapport on the: Diagnostic du secteur énergie à Madagascar, 2010, pp. 1-141.

[15] ADER, Avant Projet Sommaire du réseau hydroélectrique de Sahasinaka Fenomby - Mahabako, 2015, 1(55).

[16] Agence Internationale de l'Energie, Mini-réseaux Hybrides PV-Diésel Pour L'électrification Rurale, 2013, 34(120).

[17] Banque Africaine de Développement, OCDE, , et al.Programme de Développement des Nations Unies, African Economic Outlook, 2014, 1(25).

[18] Banque Centrale Européenne, Inflation dans la zone Euro. Accès le juillet 13, 2015. http://sdw.ecb.europa.eu/.

[19] D.F. Barnes, K. Krutilla, W.F. Hyde, The Urban Household Energy Transition: Social and Environmental Impacts in the Developing World, 2005, 15(25).

[20] V. Beguerie, K. Blanchard, RE Potential in Rural Areas, 2009, 1(25).

[21] B. Albina, Abdul Salam, Emission Factors for Wood and Charcoal-Fire Cookstoves, 2002, 1(25).

[22] A. Eberard, The Future of South African Coal: Market, Investment and Policy Challenges, 2011, 1(15).

[23] EPA, Emission Factors for Greenhouse Gas Inventories, 2014, 1(15).

[24] ESMAP, Technical and Economist Assessment of Off-Grid, Mini-Grid and Grid Electrification Technologies, 2007, 15(33).

[25] La Gazette de la Grande Ile, Services de l'électricité: les grandes lignes du futur projet PAGOSE, 2015, 1(10).

[26] L. Gianmarco, , et al.E. Miguel, La Gazette de la Grande Ile. Levelized cost of energy analysis - version 8.0, Transportation Choices and the Value of Statistical Life 1 (19) (2011).

[27] Mavethic Consulting, Compétitivité des candidats hydroélectriques, 2013, $1(12)$.

[28] MEEFM, , et al.Université d'Antananarivo Laboratoire de Recherches Appliquée, Diagnostic de l'offre nationale du secteur bois-énergie, 2015, 1(21).

[29] MEM, , et al.GIZ, Le Reboisement Villageois Individuel, 2007, 1(29).

[30] Ministère de l'Energie et des Hydrocarbures, Document de stratégie de redressement de la JIRAMA, 2019, pp. 1-121.

[31] Ministère de l'Energie, Présentation sur le mode de calcul de l'accès à l'électricité pour le Ministère de l'Economie et de la Planification, 2019, 1(29).

[32] Mission de Cadrage EUEI PDF, Rapport de Mission, 2015, 1(18).

[33] C.T.S. Nair, R. Rutt, Creating forestry jobs to boost the economy and build aGreen future, FAO 1 (121) (2009).
[34] Office de Régulation de l'Electricité, Capacité installée et en projet - RIA, 2013, 25(40).

[35] Office de Régulation de l'Electricité, Répartition des centres, 2015, 1(15).

[36] Riana, Carburants - Réunion sur la fixation des prix, Madagascar Matin 1 (10) (2015).

[37] R. Frank, Financial and Economic Assessment of Timber Harvesting Operations in the FOMISS-Samling Pilot Area (FSPA), Sarawak - Malaysia, 2001, 1(15).

[38] R.A. Ritz, Prices and Trade in Global LNG Markets, 2012, 1(55).

[39] Safe Fuel and Energy, Cooking against Climate Change: UN Judges Rwanda Project a Success, 2015, 1(33).

[40] A. Sanoh, L. Parshall, O.F. Sarr, S. Kum, V. Modi, Local and national electricity planning in Senegal: scenarios and policies 1 (19) (2012).

[41] Stockholm Environment Institute, Assessing the Climate Impact of Cookstove Projects: Issues in Emissions Accounting, 2013, 1(29).

[42] Tshiamo, Paraffin (Kerosene) Poisoning in Under-five Children: A Problem of Developing Countries, 2009, 1(18).

[43] U.S. Energy Information Administration, Annual Energy OutlookDonnées de production mondiale. Accès le Avril, 2015. http://www.eia.gov/countries/ country-data.cfm?fips=ma.

[44] U.S. Energy Information Administration, Updated Capital Cost Estimates for Utility Scale Electricity Generating Plants, 2013, 22(37).

[45] UNEP, ILO, IOE, , et al.ITUC, Green Jobs: towards decent work in a sustainable, Low-Carbon World 1 (22) (2008).

[46] S. Karekezi, Renewables in Africa - meeting the energy needs of the poor, Energy Pol. 30 (11-12) (2002).

[47] I. Motawa, Michael Oladokun, A model for the complexity of household energy consumption, Energy Build. 87 (2015) 313-323.

[48] World Energy Assessment, Chapter 2: Energy and Social Issues in World Energy Assessment, UNDP, UNDSA and World Energy Council, 2004, 1(15).

[49] Commissariat général du Développement Durable, Les Filières Industrielles Stratégiquesde L'économie Verte, 2010. www.developpement-durable.gouv. fr.

[50] Institut International du Développement durable, 2011. http://www.iisd.org/.

[51] M. Mesri-Merad, I. Rougab, A. Cheknane, et al.N.I. Bachari, Estimation du rayonnement solaireau sol par des modèles semi-empiriques, Revue des Energies Renouvelables 15 (3) (2012) 451-463.

[52] M.K. Nematchoua, R. Tchinda, N. Djongyang, P. Ricciardi, A field study on thermal comfort in naturally-ventilated buildings located in the equatorial climatic region of Cameroon, Renew. Sustain. Energy Rev. 39 (2014) 381-393.

[53] M.K. Nematchoua, C.R.R. Raminosoa, R. Mamiharijaona, T. René, J.A. Orosa, W. Elvis, P. Meukam, Study of the economical and optimum thermal insulation thickness for buildings in a wet and hot tropical climate: case of Cameroon, Renew. Sustain. Energy Rev. 50 (2015) 1192-1202.

[54] Fonds de Partenariat pour le Carbone Forestier, Proposition des mesures pour l'état de preparation (R-PP) MADAGASCAR, Date de soumission, 2010.

[55] WWF, Règlementation de la filière bois énergie dans la région Atsimo Andrefana. Acquis et leçons apprises 2008 à, 2011, 1(29).

[56] Rakotondramanana Bertholet, Le secteurélectrique: un potentiel deDéveloppementqui reste à exploiter in Madagascar: Vers un agenda de relance Economique.Une collection de notes de politiqueséconomiques. Banque mondiale, 06 April 2010, 5(25).

[57] NASA, Données sur quelques paramétres extérieures des 22dernieres années. http://eosweb.larc.nasa.gov/sse/temp/dly26871.text.

[58] T. Fatiha, Prédiction de l'irradiation solaire globale pour la région deTizi par les réseaux de neurones artificiels.Application pour le dimensionnement d'une installation photovoltaïque, 2011, 1(30).

[59] S. Karekezi, Renewables in Africa - meeting the energy needs of the poor', energy policy, special issue - Africa: improving modern energy services for the poor, Oxford Science Limited 30 (12) (2002) 11.

[60] Modeste Kameni Nematchoua, Yvon Andrianaharison, Jean Roy Sambatra Eric, Ralijaona Christian Guy, Mamiharijaona Ramaroson, Razafinjaka Jean Nirinarison, Tefy Raoelivololona, A review on energy consumption in the residential and commercial buildings located in tropical regions of Indian Ocean: a case of Madagascar Island, Journal of Energy Storage 24 (2019) 100748.

[61] National Institute of Statistics in Madagascar, Last Report of Oil Consumption, 2019. Accessed on January,5,2021.

[62] Modeste Kameni Nematchoua, Paola Ricciardi, José Orosa, Cinzia Buratti, A detailed study of climate change and some vulnerabilities in Indian Ocean:A case of Madagascar island, Sustainable Cities and Society 41 (2018) 886-898.

[63] Modeste Kameni Nematchoua, René Tchinda, Gh.R. Roshan, Paola Ricciardi, T. Nasrabadi, Climate change and its role on forecasting the Energy demand in buildings, Case study of Douala City, Cameroon, Journal of Earth Systeme Science 124 (2015) 269-281.

[64] Modeste Kameni Nematchoua, Sigrid Reiter, Analysis, reduction and comparison of the life cycle environmental costs related to an eco-neighborhood in Belgium, Sustainable Cities and Society 48 (2019) 101558.

[65] Modeste Kameni Nematchoua, Jacques Teller, Sigrid Reiter, Statistical life cycle assessment of residential buildings in a temperate climate of northern part of Europe, J. Clean. Prod. 229 (2019) 621-631.

[66] Modeste Kameni Nematchoua, Somayeh Asadi, Sigrid Reiter, Influence of energy mix on the life cycle of an eco-neighborhood, A case study of 150 countries, Renew. Energy 162 (2020) 81-97. 